\title{
Regional Flexibility Markets-Solutions to the European Energy Distribution Grid-A Systematic Review and Research Agenda
}

\author{
Tobias Rösch ${ }^{1, *}$, Peter Treffinger ${ }^{1}$ and Barbara Koch ${ }^{2}$ \\ 1 Department of Mechanical and Process Engineering, Hochschule Offenburg, 77652 Offenburg, Germany; \\ peter.treffinger@hs-offenburg.de \\ 2 Forest Research Institute Baden-Württemberg (FVA), Universität Freiburg, 79098 Freiburg, Germany; \\ barbara.koch@felis.uni-freiburg.de \\ * Correspondence: tobias.roesch@hs-offenburg.de
}

Citation: Rösch, T.; Treffinger, P.; Koch, B. Regional Flexibility

Markets-Solutions to the European Energy Distribution Grid-A Systematic Review and Research Agenda. Energies 2021, 14, 2403. https://doi.org/10.3390/en14092403

Academic Editor:

Dimitrios Katsaprakakis

Received: 4 April 2021

Accepted: 19 April 2021

Published: 23 April 2021

Publisher's Note: MDPI stays neutral with regard to jurisdictional claims in published maps and institutional affiliations.

Copyright: (C) 2021 by the authors. Licensee MDPI, Basel, Switzerland. This article is an open access article distributed under the terms and conditions of the Creative Commons Attribution (CC BY) license (https:/ / creativecommons.org/licenses/by/ $4.0 /)$.

\begin{abstract}
The German government is aiming to increase the share of renewable energies in the electricity supply to $80 \%$ in 2050 . To date, however, neither the technical requirements nor the market requirements to implement this aim are provided: Germany is struggling to establish the technical requirements and the market requirements to meet this goal. As an important incentive mechanism, the German government has used and continues to use support measures, such as guaranteed feed-in tariffs, and continuously adapts these to market developments and requirements of the European Union. The purpose of the study is to outline a concept for the implementation of regional flexibility markets in Europe based on a thorough review of technical solutions. The method of a comprehensive review of research in regional flexibility markets of electricity, distribution, and pricing from the study is applied to summarize and discuss the opportunities, risks, and future potentials of grid distribution technology. Based on the insights, a new market-based supply and distribution scheme for electricity, which is aimed to benefit of a fully regenerative, decentral and fairly priced electricity markets on the European level is presented. The study suggests a blockchain based pricing mechanism which shall allow equal market access for consumer, providers, and grid operators and rewards regenerative production and short-distance transmission.
\end{abstract}

Keywords: energy policy Germany; EEG; electric power grids; power grid stability; photovoltaic wind energy; pricing

\section{Introduction}

Industrialized countries' growing hunger for energy threatens the ecological equilibrium of our planet [1]. On a world-wide scale, the major of energy production to date is mainly based on fossil resources and nuclear energy. The latter entails incalculable risks to mankind in case of nuclear accidents [1], and, to date, no sustainable recycling technology for nuclear waste has been found [2]. The combustion of oil and gas causes enormous emissions of $\mathrm{CO}_{2}$ and noxious gases. Noxious emissions cumulate in the air and pollute the environment. $\mathrm{CO}_{2}$ decreases the penetration of infrared radiation reflected by the earth, which leads to global warming, due to increased protrusion of solar radiation in lower atmospheric levels [3]. Climatic change, desertification, the melting of polar ice, and an increase of sea levels threaten plants, animals, and human populations predominantly in warm climatic regions [4-6]. The dying of species, global migration, and conflicts are the results of large-scale energy resource consumption [7-9].

\subsection{Germany's Commitment to Switch to Regenerative Energies (Energiewende)}

Figure 1 illustrates the first half of 2020, Germany's energy mix comprised $20 \%$ coal, $12.4 \%$ nuclear energy, $12.1 \%$ gas, and 55\% renewables, among them wind $(31 \%)$, solar power $(11 \%)$, biomass $11 \%$, and water power (4\%) [10]: 


\section{Sources of electricity (Germany)}

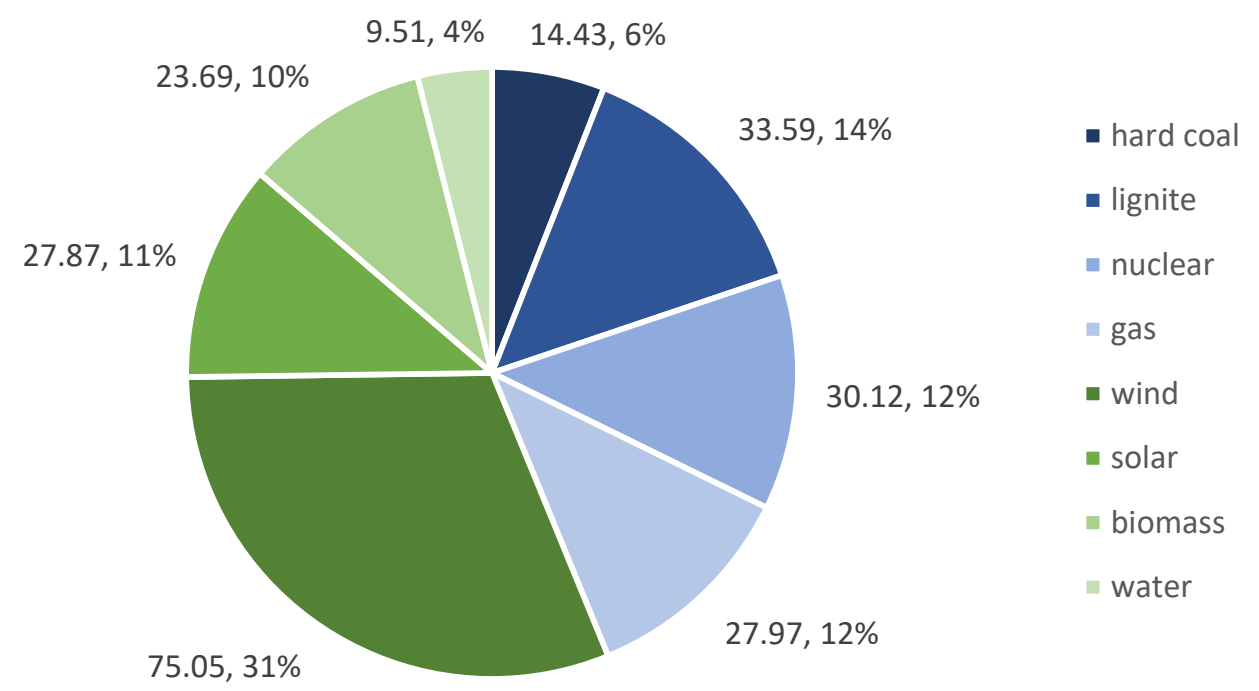

Figure 1. Sources of Germany's electricity [11].

Lignite represents a key element in the German energy supply. However, it is a very $\mathrm{CO}_{2}$ intensive energy resource. The following Figure 2 shows the development of lignite mining in Germany since 1990.

\section{Lignite production in Germany from 1999 to 2019}

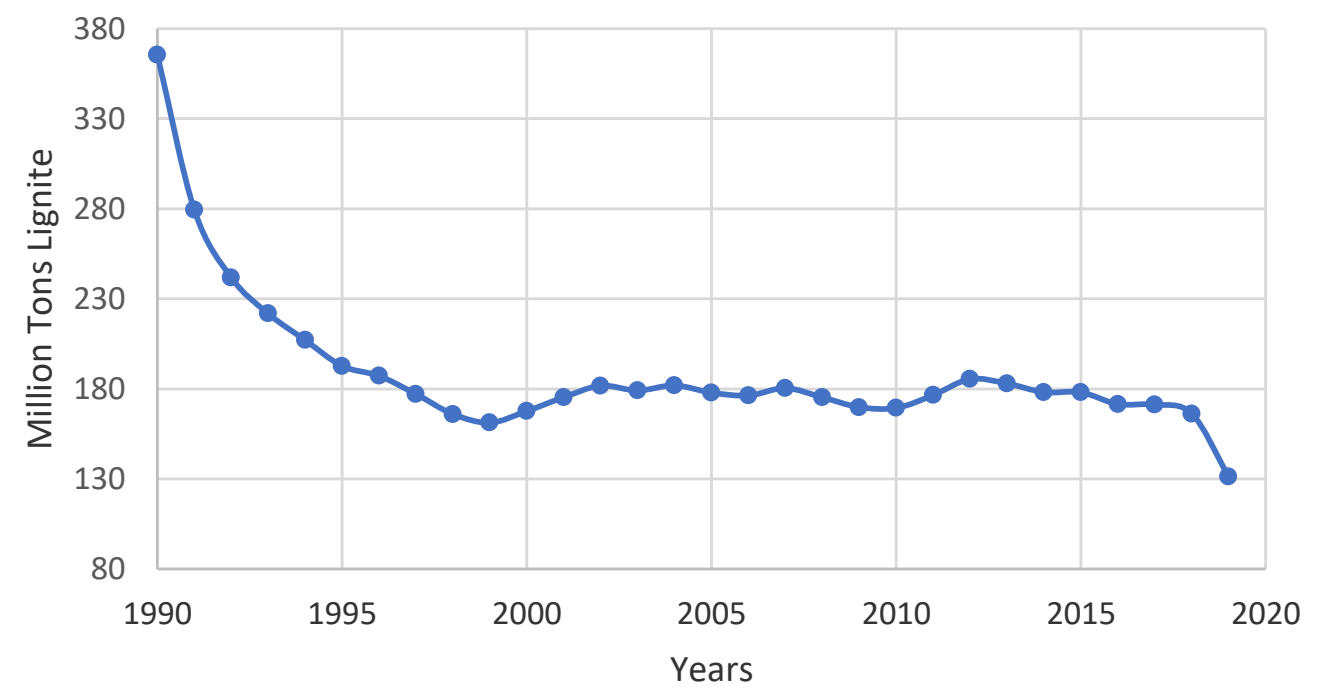

Figure 2. Lignite production in Germany from 1999 to 2019 [12].

The output of brown coal had a sharp drop in the period from 1990 to 1996 but has stayed on that level since. Only from 2019 has a further drop in the production of lignite can be seen. 
The German government has recognized the threats and difficulties of the remaining $49.5 \%$ nuclear and fossil power generation. In 2011, the government changed the nuclear power law and advanced the phase out from nuclear energy to the end 2022 [13]. In addition, in 2010, they have committed to strongly reduce emissions and side effects of electricity generation by switching its production scheme from fossil fuel power stations and nuclear power stations to mainly regenerative production until 2050 [14]. In its 2010 working paper, the German government explains that its greenhouse gas emissions are meant to be reduced by $80 \%$ until 2050 , and the share of regenerative energies is increased to $80 \%$ of final energy supply in the electricity sector. Further, comparable targets are set for decarbonization in the heat sector and transport sector. This target has been implemented in the EEG (Erneuerbare Energiengesetz, German regenerative energy law), which plans a gradual substitution of non-sustainable energies, to a supply of $40 \%$ to $45 \%$ of regenerative resources until 2025, 55\% to $60 \%$ until 2035, and 80\% until 2050 [15]. Annual development targets by energy carrier are planned for wind energy, solar energy and biomass [16]. This eager target is meant to be realized for the electricity sector by shutting down conventional coal, gas, and nuclear power plants and substituting them by wind parks located in the Northern Sea, biogas plants, and CSS gas and coal plants, which retrieve and store $\mathrm{CO}_{2}$ emissions [17]. Expand transmission capacity are meant to transmit and deliver electrical energy harnessed from renewable energies to consumers all over Germany. To buffer intermittent sustainable energy resources decentral storage systems, e.g., battery-electric cars, hydrogen, methane, and thermal storage units are meant to be developed [18].

\subsection{Price Regulation Policy}

Obviously, the planned turn-around of Germany's energy policy requires significant investments. The German government estimates expenses of 20 billion euros per year, altogether forty times 20 billion or 800 billion Euros to adapt the German energy sector in the described form, starting in 2010 until 2050 [11]. Energy providers in Germany and all around the globe face significant cost pressures to meet the requirements of the regenerative energy shift $[19,20]$.

To finance this effort and encourage stakeholders to invest in the change, the government has decided for a subsidy which has been written down in the electricity feed-in law (Stromeinspeisungsgesetz (StromEinspG)) of 1991 and reformed with the EEG (Erneuerbare Energien Gesetz). The law came into force in 2000 and has regularly been adapted to the development of regenerative resources. It prioritizes electrical energy from regenerative resources in the German electricity market. It obligated grid operators to purchase electrical energy from renewable sources and to pay for it in accordance with the requirements of the EEG [21]. Until EEG 2014, the price to be paid for regenerative electricity by German consumers had been fixed by the government annually, which resulted in significant misallocations and rent-seeking behavior, due to a decoupling of investment costs and granted compensations [22].

Since EEG 2017, the value or, respectively, price of regenerative energy in Germany is partly determined in a tendering process, i.e., a "transparent, non-discriminatory and competitive procedure to determine the beneficiary and the value to be invested" [23] by energy type (on-and offshore wind energy, solar energy, and biomass) and on a monthly basis [24] by the German government. Grid operators have to accept regenerative energy at the defined price, no matter whether a feed-in contract with the provider has been concluded (legal obligation) [25] and have to provide access to their grid without delay at the nearest technically adequate access point, even if this requires grid remuneration [26]. The grid operator is liable for remuneration costs [27], but feeders of more than $100 \mathrm{~kW}$ capacity have to ensure that the feed-in can be reduced by the operator in case of grid overload [28]. Grid operators can charge costs for grid remuneration to consumers by an additional grid fee on the electricity price. Providers of more than $750 \mathrm{~kW}$ of installed regenerative power are authorized to apply for the market-premia plus (based on tender assignment) and a feed-in tariff (Einspeisevergütung), which is paid for a period of 20 years 
after the start of operation of the plant [29]. Smaller providers receive the feed-in tariff only and are not admitted to the tender process. Energy volumes accepted for the feed-in tariff are defined by energy type and are fixed in § 28 EEG 2017 for the years 2019, 2020, and 2021. Tender offers are submitted by the plant operators for a defined amount and at a defined price per kWh [30] and are considered by order of prices [31]. The EEG 2017 regulations are valid for German regenerative providers mainly; only $5 \%$ providers from other European countries are admitted [32].

To solve this complex situation, Germany and Europe urgently require novel electricity market models to amend distribution and pricing. The study suggests regional flexibility markets to maximize economic incentives for regenerative supply and reviews available technologies for the implementation of flexible market mechanisms to provide a viable solution to German's energy dilemma.

This complex research objective for the first time integrates two research disciplines: One strand of research discusses regional flexibility markets as a political solution but did not work on technologies for their implementation. The second strand of research develops technologies for more efficient electricity distribution and pricing but does not refer to flexibility markets. Here, a new electricity market approach for Europe is suggested based on a review of technical options to implement it.

The remainder of the study is organized as follows: Section 2 informs on German's dilemma in the switch towards a fully regenerative electricity market and suggests local flexibility markets as a promising market model. Section 3 reviews concepts to implement regional flexibility markets documented in academic research and finds that blockchain technology adequate to solve the present distribution and organization problem. Section 4 develops an implementation scheme for local flexibility markets based on blockchain technology for Germany and Europe. Section 5 discusses limitations to the approach and provides policy suggestions.

\section{Germany's Dilemmas of Electricity Distribution and Allocation}

The practical implementation of Germany's Energiewende ("energy shift") under EEG 2017, however, incurs technical implementation problems and unfolds adverse price effects for private and commercial electricity consumers.

\subsection{Degressive Regenerative Resource Output}

The share of regenerative energies from gross electricity consumption increased from $37.8 \%$ in 2018 to $42.1 \%$ in 2019 , which means a plus of $9 \%$ to 244.3 TWh [33]. The rise is partly due to the addition of installed capacity and partly due to above-average full load hours in the respective years. The main growth of regenerative electricity supply in 2019 was from wind energy, which realized an increase of $15 \%$ compared to 2018, mainly due to strong wind season, while the installed capacity increased by $2.5 \%$ compared to 2018 only. Photovoltaic energy increased by $4 \%$ mainly due to additional plant construction and a sunny June 2019. In 2019, hydro energy generation increased by $12 \%$ compared to 2018 , which had been a rather dry year. No new hydro power plants were installed. Biomass energy diminished by about $1 \%$ compared to 2018 , and there were no plants added. Altogether, installed regenerative capacities increased at a degressive pace and by $5.2 \%$ in 2019 compared to 2018 [34].

Assuming that electricity consumption remains unchanged, electricity generation by renewables and accordingly installed production capacities presumably have to almost double until 2050 to meet the objective of the EEG of covering $80 \%$ of consumption from regenerative resources. The Umweltbundesamt (German environment authority) [35], however, assumes that $100 \%$ regenerative energies will be required to meet the $\mathrm{CO}_{2}$ targets. Growing e-mobility and the increasing prevalence of electronic devices lead to a substantial higher electricity and consequently higher installed capacities of renewables [36].

The major regenerative resources, wind, solar, hydro, and biomass, however, dispose of limited growth potential. 
Germany's expansion potential of hydro energy is close to zero for ecological reasons: hydro energy output is fluctuating by about $15 \%$ annually and has contributed a share of 2.9 to $4.3 \%$ to Germany's annual electricity consumption since 1992. Eighty percent of hydro energy originates from the large-scale hydro power plants [37].

From 2016 to 2020, the increase of on-shore wind energy has steadily been consolidating [38]. The share of newly built wind power plants is at the lowest level since 1998, and, in 2020 to date only 276 wind power plants with a total capacity of $940 \mathrm{MW}$ have been installed. To reach the 2030 target, it is estimated that an annual increase in installed wind power of $2.3 \mathrm{GW}$ to $4.3 \mathrm{GW}$ would be required. However, Germany's wind energy sector is in a critical situation: Due to low acceptance of wind turbines among the German population, new regulations demand a $1000 \mathrm{~m}$ distance of new plants from existing houses. Only a small fraction of existing plants meets these requirements, which means that hardly any sites for new on-shore constructions are available [39].

Offshore wind energy has got large development potential globally. With 15,800 MW of installed capacity, Europe holds more than $84 \%$ of global offshore capacities and equally accounts for the highest growth in 2017/18 [40]. German companies put three offshorewind parks of $1111 \mathrm{MW}$ in 2019 into operation so that, as of 2020, 1470 off-shore wind plants off $7500 \mathrm{MW}$ capacity are in operation, and offshore wind energy has a share of $10 \%$ of the renewable electricity generation. Since 2014, off-shore wind energy output has grown progressively, but the expansion is about to come to a temporary halt: In 2020, only $206 \mathrm{MW}$ or 30 wind turbines were added. Concerns about the negative impact on marine habitats and sea currents have led to lengthy approval processes and ecological restrictions [41]. The insolvency of wind turbine manufacturer Senvion has further delayed the expansion process, and, since 2018, only two new offshore windfarms of altogether 312 MW capacity are under construction, which, due to long planning and installation periods, implies that off-shore wind energy growth will come to a temporary halt in 2021 [42].

Photovoltaic energy disposes of the second largest share in regenerative production of $20.4 \%$ by 2019 . Solar electricity generation increased by $4 \%$ in 2019 . In total, $49,016 \mathrm{MW}$ of capacity are installed in Germany as of today [29]. Solar energy has still a high development potential, since approval processes are less complicated than for windfarms, the landscape impact of solar panels is low [43], and many small providers could contribute.

Summarizing the technical growth potentials of the regenerative electricity sectors, hardly any further expansion in biomass plants and hydro power plants is expected for environmental reasons. On- and offshore wind power expansion has significantly slowed down due to novel regulations. Solar power still offers significant growth potential. Given the expansion limits of hydro power, biomass, and onshore wind power plants, the rapid expansion of solar power and long-term expansion of off-shore wind power plants are essential to meet the EEG targets in the years to come (55\% to $60 \%$ of regenerative energy until 2035).

\subsection{Grid Capacity Restrictions}

Grid and storage capacity problems, however, question the technical expansion potential of these promising regenerative electricity sources:

The weak transmission capacities from off-to onshore grids are a fundamental reason for the delay in offshore-capacity growth: Only three transmission stations are available at present, one of which (Dörpen-West) manages about $50 \%$ of off-shore wind energy generated in North Sea wind farms [44]. To distribute electricity generated in the northern seas to the southern parts of the country, the high voltage train capacities of transmission system operators have to be remunerated, which requires lengthy approval processes and has provoked resistance among the population [45]. 
In contrast to off-shore wind energy, photovoltaic energy is generated decentrally and all over Germany. Provided that local grids operated by distributions system operators (DSO) work efficiently, photovoltaic feed-in can, thus, be used locally, which saves transportation losses and the remuneration of long-distance transmission grids [46]. However, a major share of the existing regional grids is no more adequate in their structure to cope with the changing patterns of energy flow induced by growing feed-in from local photovoltaic system operators [47].

\subsection{Pricing Dilemma}

The pricing scheme of EEG 2017, however, prevents that production and distribution structures adapt to changing technological options and market requirements:

According to EEG 2017, Germany's renewable energy providers are assigned a compensation comprising a monthly variable "market premia" determined in a tender process", and a fixed feed-in tariffs fixed for 20 years from start of operation [24]. The market premia are between $0.05 € / \mathrm{kWh}$ and $0.06 € / \mathrm{kWh}$ presently, depending on the energy source [37]. The feed-in compensation is between $0.06 € / \mathrm{kWh}$ and $0.09 € / \mathrm{kWh}$ for photovoltaic energy and has been decreasing steadily in recent months, due to the approval of numerous new plants [48]. Wind power plants obtain feed-in compensations of $0.05 € / \mathrm{kWh}$ to $0.06 € / \mathrm{kWh}$ as of August 2020 up from $0.04 € / \mathrm{kWh}$ in 2019 (depending on the plant type and month of first commissioning). Until 2012, $0.092 € / \mathrm{kWh}$ start-up compensation or the first years of operation were paid according to EEG 2009 [49]. In summary, operators of renewable electricity systems earn a fee of $0.1 € / \mathrm{kWh}$ to $0.15 € / \mathrm{kWh}$, depending on primary energy source, tender participation, realized tender prices and start of operation.

This regulation scheme unfolds negative economic impacts on (a) renewable electricity systems operators, (b) grid operators, and (c) consumers:

(a) Provider impact

When investing in renewables, operators incur significant expenses and have to amortize these investments, plus fixed operation and maintenance costs over the lifetime of the plant from construction to dismantling. Based on the EEG 2017 allocation scheme, they are assigned a fixed feed-in compensation but cannot rely on the market premia, which they obtain only when they are considered in the tender process, which means significant investment uncertainty, in case the fixed feed-in fee does not cover the levelized cost of electricity (LCOE) of the respective plants. The negative incentive impact of the tender pricing system is obvious when evaluating, assigned tenders: At the tender market prices for wind energy in June 2020 averaging $0.0607 € / \mathrm{kWh}$, only about half of the tender amount for wind power plants according to EEG 2017 was filled. In the solar energy segment market, on the other hand, price offers in June 2020 averaged $0.0527 € / \mathrm{kWh}$, and only a quarter of the offers (96 MW) amounting to 447.23 MW were considered [37]. Obviously, past incentives for installing wind energy were too low (as compared to EEG targets), so that too few wind plants have been built, while solar plants have been supported too strongly in the past so that now the installed capacity is too high at the governmentally assigned price of about $0.15 € / \mathrm{kWh}$ in total.

Until 2030, an expansion to 15 GW of offshore capacities is planned according to EEG 2017 [37]. Starting in 2021, wind turbines that were built 20 years ago and are now no longer eligible for the EEG provisions in effect at the time of construction are expected to be decommissioned and dismantled [50]. Dismantling of wind power plants shall cause costs of around 300 million euros in this decade. It seems that dismantling costs are, in many cases, not covered by operators' revenues. Therefore, the question arises to what extent the feed-in tariff granted under the EEG actually covered costs when considering the entire life cycle of a wind turbine [51].

It is argued that the tender and amount of regulation of EEG 2017 do not boost the expansion of required solar and off-shore wind capacities strong enough, since presently granted compensations question the profitability of these technologies for operators [52]. 
Onshore-Wind energy provision is rewarded by EEG 2017, but additional plants are hardly admitted due to regulations on distance to settlements [53].

To benefit from the EEG laws, renewable electricity systems operators incur significant bureaucratic efforts. New plants have to be registered with authorities and grid operators to benefit of the feed-in gratification [54]. To obtain the market premia, suppliers have to participate in the auction scheme on a monthly basis and according to a tight schedule. Inclusion in the tender scheme results in further reporting requirements of generated electricity amounts [49].

In the present tendering system, operators of small-scale renewable electricity systems, namely private PV system operators, are excluded from the market premia: Only operators of PV systems with capacities above $750 \mathrm{~kW}$ are admitted for and obliged to participate in the EEG 2017 "market" scheme. They have to fulfil technological qualifications and make a deposit to guarantee that the selected projects are implemented [55]. The effect is that small operators rather utilize generated electricity for themselves and save the market price of $0.3 € / \mathrm{kWh}$ instead of feeding in on the grid at the fixed feed-in premium of $0.1 € / \mathrm{kWh}$. Operates of PV systems exceeding a capacity of $10 \mathrm{~kW}$ even have to pay $40 \%$ of the annual EEG apportionment, regardless if the electricity is self-consumed [56]. This regulation disadvantages operators of small-scale PV systems and reduces the willingness of private homeowners to invest in PV.

Operators of renewable electricity systems from other European countries are hardly admitted to the German EEG-based subsidy scheme, which causes inequalities and imbalances in the European market [57].

(b) Grid operator impact

Grid operators in the transmission and distribution grid, dispose of power line planning times of ten or more years [58]. They have to rely on stable operation prognoses by energy type and provider size and location. Under the present EEG 2017 allocation scheme, allocations for the energy sources change annually, but EEG 2017 fixes feed-in amount until 2021 only [59]. After that an amendment to the EEG will define new tender amounts. While some plants and energies will lose in profitability, others will open up. It is argued that, under the current policies, network operators lack a stable basis for planning investments [60]. This situation hampers operators' willingness to invest in grid infrastructure

Legal regulations in Germany supervise, define, and limit operation and investment costs transmissions grid operators can charge via grid fees. The legally chargeable costs are defined based on a formal calculation scheme, which is to be submitted in the planning phase which imposes cost limitations later on according to $\S 23 \mathrm{ARegV}$, but leave the planning, implementation and operation risks to the transmission grid operators, which impairs their readiness to invest in transmission grid remuneration [61]. The quality of grid infrastructure, however, codetermines the operation efficiency of off-shore farms, since energy losses frequently result from problems on the transmission grid [62]. To ensure grid stability, the feed-in power of renewable energy plants must be temporarily restricted, i.e., reduced or interrupted.

Grid operators incur significant transaction cost and bureaucratic efforts to settle investment expenses for grid development with authorities [63] and to price and bill electricity to consumers. To compensate grid operators for the excess costs of buying regenerative electricity from feeders on their grid, the German federal government has designed an EEG levy, consumers are charged on the specific electricity price [64]. Grid operators are responsible for allocating the EEG apportionment to suppliers and among each other according to $\S 72$ EEG 2017. That means DSO (distribution systems operators) have to currently inform TSO (transmission systems operators) on providers and provider changes on their grid, the costs for remuneration and the amount and type of payments they have received. TSO have to settle up EEG levy with suppliers annually. Grid operators hedge price difference between European spot market prices and German supplier and consumer prices on their own account [65]. 


\section{(c) Consumer impact}

EEG supply-pricing policy impacts consumer prices of electricity from regenerative resources: The fees of $10 \mathrm{ct} / \mathrm{kWh}$ to $15 \mathrm{ct} / \mathrm{kWh}$ for renewable energies assigned to providers by the German government exceeds the European exchange price for electricity, which fluctuates on a daily basis and was $23 € / \mathrm{MWh}$ to $28 € / \mathrm{MWh}$, or 2.3 to $2.8 \mathrm{ct} / \mathrm{kWh}$, in 2019 , a yearlong low as compared to peak prices of $70 € / \mathrm{MWh}(7 \mathrm{ct} / \mathrm{kWh})$ in Nov, 2018 [66]. Obviously, generation cost of electricity generated from fossil or nuclear fuel are significantly lower than feed-in tariffs granted under the EEG scheme.

German consumers are charged the EEG levy as an add on to the electricity price, whether or not they purchase regenerative electricity [67]. Since 2006, household consumer (average $3.500 \mathrm{kWh}$ p.a.) electricity prices in Germany have been on a steady increase von 19.46 to $30.43 \mathrm{ct}$ per $\mathrm{kWh}$ on average. The cost of procurement has been fluctuating between $5 \mathrm{ct} / \mathrm{kWh}(2005,2017)$ and $8 \mathrm{ct} / \mathrm{kWh}(2012)$. Grid usage fees have been increasing only slowly from $6 \mathrm{ct} / \mathrm{kWh}$ to $7.4 \mathrm{ct} / \mathrm{kWh}$. Taxes, levies, and charges on the consumer electricity price, however, have more than doubled, from $7.61 \mathrm{ct} / \mathrm{kWh}$ in 2006 to $15.98 \mathrm{ct} / \mathrm{kWh}$ in 2019 [68]. Similarly, industry customer prices for electricity have increased from $11.5 \mathrm{ct} / \mathrm{kWh}$ in 2006 to $18.55 \mathrm{ct} / \mathrm{kWh}$ in 2020 [69]. Government charges and fees account for more than half of German consumers' and businesses' electricity expenses. This reflects that the major portion of the cost for the transition of energy system is finally charged to the electricity consumers, namely private households and industrial companies.

Other European countries do not follow this scheme, however: Electricity prices German consumers had to pay in 2019 were the highest among all European countries. These started from $9.97 \mathrm{ct} / \mathrm{kWh}$ in Bulgaria. $20.34 \mathrm{ct} / \mathrm{kWh}$ were charged in Austria, $21.22 \mathrm{ct} / \mathrm{kWh}$ in Great Britain, $20.15 \mathrm{ct} / \mathrm{kWh}$ in Sweden, and $17.565 \mathrm{ct} / \mathrm{kWh}$ in France. Due to the joint electricity spot market, price differences result from differences in fees and charges mainly, and these are highest in Germany and Denmark [70]. Germany is among the top three (together with Cyprus and Italy, concerning prices for non-household consumers, and imposes the highest tax and fee burden (exempting VAT) among all European countries. While in EU-28 (and equally China and the USA [71]) non-household electricity prices have remained stable since 2013 , German businesses saw electricity price increased by about 30\% [72].

This policy means significant macroeconomic disadvantages for German businesses in European comparison. Energy intensive industries have a strong incentive to settle in other European countries [73]. A good deal of the expenses for the sustainable reconstruction of Germany's economy is in jeopardy because of bureaucratic obstacles under the present scheme.

\section{A Review Regional Flexibility Market Concepts-A Solution to Germany's Energy Issue?}

Electricity providers and commercial consumers have been calling for higher flexibility to enable market demand and supply to meet at market conditions [74,75]. Academic research provides diverse approaches to how the above distribution dilemma could be resolved. A systematic literature overview on studies discussing technologies to improve electricity distribution in regional grids is devised to provide an overview on the technical options and develop a preliminary action plan to implement a "regional flexibility market scheme".

\subsection{Concept of Regional Subsidiary Flexibility Markets}

Flexibility means adaptiveness of technical systems or economic schemes to changing requirements or market demands in dimensions, timing, range, intention, and focus [76].

Subsidiarity is a socio-political principle, according to which superior social units (especially the state) may only take on those tasks that subordinate units (e.g., individuals or local communities) are not able to perform [77]. Subsidiarity of electricity grids means 
that local solutions for grid problems are attempted, and higher grid levels are involved only when this is impossible [78].

Correspondingly, the aim of regional subsidiary flexibility markets is to enhance the technical and economic efficiency of regenerative electricity supply systems based on the subsidiary interaction of market participants. The flexibility market model suggests a "cellular" approach to determine the energy requirement at the level of local individual units, rather than top down according to a total calculation of expected demand and supply (as under the present EEG 2017 scheme) [79]. Cellular entities are represented by quarters or local industrial agglomerations. In these units, energy is generated, e.g., by photovoltaic plants and combined heat and power units, stored, e.g., by local storage units and electric cars and consumed, e.g., by household devices or industrial machinery [80]. The flexibility market approach suggests that these regional units should interact to attain a maximum level of subsidiarity, while only peak loads and peak feed-ins are buffered outside the local community, e.g., in transmission grids [81].

The regional flexibility approach minimizes transportation efforts and losses, improves grid stability, by reducing loads on large transmission grids, avoids the construction of additional transmission grids [82]. It reduces bureaucratic efforts for all market participants, and is flexible to adapt to new technological requirements due to the self-determination and cost-profit responsibility of a limited number of participants in the cellular unit [76]. From outside, e.g., from the perspective of transmission grid operators, the whole cell is treated like a single provider, since only production surpluses or deficits of the cell spill over in the external grid [83].

Different requirements of local entities and independent flexible supply decisions should be respected [78]. Flexibility of energy systems should include energy production, distribution and consumption under flexible pricing schemes [84].

Bundesnetzagentur demands that electricity prices should reflect electricity scarcity in the supply market. Grid fees, on the other hand, should represent the costs of using the grids. Both scarcity signals should guide consumption behavior. An improvement of grid infrastructure should ease regional electricity supply. At the same time, the cost structure should avoid high administrative efforts and grant free competition [85]. The discussion paper, however, does not detail technical approaches how these objectives could be realized:

\subsection{Review Method and Overview of Results}

A systematic review of academic literature is useful to differentiate and explain available technical standards and discuss the advantages, present limitations and future potentials of the technologies. To gain an overview of available technologies in the field of electricity distribution, a thorough review methodology is required, which identifies relevant and founded studies systematically and allows to trace the main developments in the field. The review focuses on empirical research in distribution grid technology published in academic journals in the period 2018 to 2020, to focus on the most recent insights. Twenty-seven studies meeting these requirements are retrieved and evaluated as to the described technologies, their opportunities, limitations, and future potentials.

To structure the results based on available technologies, a methodology suggested by Webster and Watson [86] is applied: It classifies retrieved studies in a content matrix organized by authors and the above categories of analysis first. The results are organized by technologies then, to gain relevant main and subcategories (of technologies), which are the basis for textual analysis and comparison. The second analytical step is performed in the form of a mind map here.

Table 1 summarizes the retrieved studies by the major technologies, their stage of practice implementation, and main points made. 
Table 1. Overview on reviews studies discussing technologies to realize "regional flexibility markets.

\begin{tabular}{|c|c|c|c|c|}
\hline Author, Year & Technology & Advantages/Potentials & $\begin{array}{c}\text { Limitations/Development } \\
\text { Needs }\end{array}$ & $\begin{array}{l}\text { Applicability } \\
\text { Level }\end{array}$ \\
\hline $\begin{array}{l}\text { Ambrosius et al. } \\
2018 \text { [87] }\end{array}$ & Price zone optimization & $\begin{array}{l}\text { Welfare gains by price } \\
\text { zone } \\
\text { Dynamic pricing } \\
\text { techniques }\end{array}$ & $\begin{array}{l}\text { Complex and dynamic } \\
\text { determination of price } \\
\text { zones }\end{array}$ & Case study (virtual) \\
\hline Andoni] 2019 [88] & $\begin{array}{l}\text { Applications of } \\
\text { blockchain technology in } \\
\text { energy grids: grid } \\
\text { management, decentral } \\
\text { training, stationary \& } \\
\text { mobile feed in metering } \\
\text { \& coordination }\end{array}$ & $\begin{array}{l}\text { On-time coordination } \\
\text { between grid operators } \\
\text { Availability planning and } \\
\text { recording of energy } \\
\text { market participants }\end{array}$ & $\begin{array}{l}\text { Limited through put and } \\
\text { transaction speed }\end{array}$ & Conceptual stage \\
\hline $\begin{array}{c}\text { Agung and } \\
\text { Handayani, } 2020 \\
{[89]}\end{array}$ & $\begin{array}{l}\text { Blockchain to manage } \\
\text { smart grid transactions }\end{array}$ & $\begin{array}{l}\text { Implementation, } \\
\text { verification and } \\
\text { recording of small user } \\
\text { interactions }\end{array}$ & $\begin{array}{l}\text { Limited transaction } \\
\text { frequency } \\
\text { Price sensitivity to } \\
\text { speculation } \\
\text { Computer performance } \\
\text { limits } \\
\text { Criminal attacks }\end{array}$ & Conceptual stage \\
\hline $\begin{array}{l}\text { Alskaif and van } \\
\text { Leeuwen, } 2019 \text { [90] }\end{array}$ & $\begin{array}{l}\text { Private blockchain test in } \\
\text { Amsterdam based on } \\
\text { optimal power flow } \\
\text { model \& smart contracts }\end{array}$ & $\begin{array}{l}\text { Direct interconnection of } \\
\text { provider / consumers } \\
\text { without third party }\end{array}$ & $\begin{array}{c}\text { Attack proof but only } \\
\text { tested in small grid } \\
\text { Payment scheme required } \\
\text { based on available } \\
\text { electricity amount }\end{array}$ & Practice test \\
\hline $\begin{array}{l}\text { Alskaif and van } \\
\text { et al., } 2020 \text { [91] }\end{array}$ & $\begin{array}{l}\text { Blockchain application } \\
\text { for operational planning } \\
\text { and scheduling, smart } \\
\text { metering and verification } \\
\quad \text { \& settlement }\end{array}$ & $\begin{array}{c}\text { Lower entrance barriers } \\
\text { to electricity markets } \\
\text { Higher transparency \& } \\
\text { liquidity }\end{array}$ & $\begin{array}{l}\text { Limited number of } \\
\text { participants and high } \\
\text { transaction times due to } \\
\text { technical limitations } \\
\text { Coordination by "virtual } \\
\text { grid operator" to keep } \\
\text { control }\end{array}$ & Conceptual stage \\
\hline Devine, 2019 [92] & $\begin{array}{l}\text { Demurrage (devaluation } \\
\text { in time) system for } \\
\text { energy trading in } \\
\text { blockchain (national } \\
\text { token marketplace) }\end{array}$ & $\begin{array}{l}\text { Incentivize energy } \\
\text { consumption when local } \\
\text { abundance } \\
\text { Alignment of demand \& } \\
\text { supply }\end{array}$ & & Conceptual stage \\
\hline D’Oriano, 2018 [93] & $\begin{array}{l}\text { Blockchain for smart } \\
\text { energy contracts based } \\
\text { on penalties and } \\
\text { incentives to control } \\
\text { power flows }\end{array}$ & $\begin{array}{c}\text { Automatic control of } \\
\text { prosumers enhances grid } \\
\text { stability } \\
\text { Tamper proof } \\
\text { documentation }\end{array}$ & & Conceptual stage \\
\hline Fang, 2019 [94] & $\begin{array}{l}\text { Blockchain to control } \\
\text { energy flows, } \\
\text { information and } \\
\text { communication }\end{array}$ & $\begin{array}{c}\text { Enable bidirectional } \\
\text { power flows } \\
\text { Failure protection } \\
\text { Coordination and } \\
\text { communication of } \\
\text { participants }\end{array}$ & $\begin{array}{l}\text { Diffusion of smart meters } \\
\text { among small prosumers } \\
\text { Costs for smart metering, } \\
\text { grid maintenance } \\
\text { Complex and defect-prone } \\
\text { communication } \\
\text { infrastructure }\end{array}$ & Conceptual stage \\
\hline
\end{tabular}


Table 1. Cont.

\begin{tabular}{|c|c|c|c|c|}
\hline Author, Year & Technology & Advantages/Potentials & $\begin{array}{c}\text { Limitations/Development } \\
\text { Needs }\end{array}$ & $\begin{array}{l}\text { Applicability } \\
\text { Level }\end{array}$ \\
\hline Gao, et al. 2018 [95] & $\begin{array}{l}\text { Sovereign blockchain } \\
\text { technology based on } \\
\text { smart metering, use of } \\
\text { private tokens }\end{array}$ & Transparency of origin & $\begin{array}{c}\text { Avoids: Abuse of sensitive } \\
\text { data }\end{array}$ & Conceptual stage \\
\hline $\begin{array}{c}\text { Gong et al., } 2020 \\
{[96]}\end{array}$ & $\begin{array}{c}\text { Semi-centralized- } \\
\text { Blockchain technology } \\
\text { located at energy routers } \\
\text { at transmission \& } \\
\text { distribution networks }\end{array}$ & $\begin{array}{c}\text { Enhanced network } \\
\text { control } \\
\text { Double stability control } \\
\text { Bottom-up control } \\
\text { mechanism for } \\
\text { autonomous energy } \\
\text { coordination }\end{array}$ & $\begin{array}{l}\text { Bidirectional power flow } \\
\text { complicates grid control \& } \\
\text { coordination }\end{array}$ & Conceptual stage \\
\hline $\begin{array}{c}\text { Guan et al., } 2018 \\
\text { [97] }\end{array}$ & $\begin{array}{l}\text { Smart metering: privacy } \\
\text { efficient data aggregation } \\
\text { scheme in blockchain } \\
\text { groups }\end{array}$ & $\begin{array}{l}\text { Collect private electricity } \\
\text { consumption (habits) }\end{array}$ & $\begin{array}{c}\text { Users' privacy } \\
\text { Develop pseudonyms }\end{array}$ & Practice test \\
\hline $\begin{array}{c}\text { Kotthaus et al., } 2018 \\
\text { [98] }\end{array}$ & $\begin{array}{l}\text { Local flexibility markets } \\
\text { in an auction timetable, } \\
\text { traffic light concept to } \\
\text { schedule grid inflow }\end{array}$ & $\begin{array}{l}\text { Concrete scheme for grid } \\
\text { facility planning }\end{array}$ & $\begin{array}{c}\text { Lack of liquidity and gaps } \\
\text { between individua grid } \\
\text { territories }\end{array}$ & Conceptual stage \\
\hline $\begin{array}{c}\text { Kouveliotis- } \\
\text { Lysikatos, } 2019 \\
\text { [99] }\end{array}$ & $\begin{array}{l}\text { Smart grid applications } \\
\text { with blockchain vehicle } \\
\text { and central contract }\end{array}$ & $\begin{array}{l}\text { Decentralized markets } \\
\text { in microgrids already } \\
\text { existent }\end{array}$ & $\begin{array}{l}\text { Smart meters have to be } \\
\text { reliable } \\
\text { Infrastructure operator has } \\
\text { to be trusted }\end{array}$ & Conceptual stage \\
\hline $\begin{array}{l}\text { La Fauci et al., } 2018 \\
\text { [100] }\end{array}$ & microgrids & $\begin{array}{l}\text { Lowering costs for } \\
\text { communication, control } \\
\text { and equipment }\end{array}$ & $\begin{array}{l}\text { Lack of a homogenous } \\
\text { standard }\end{array}$ & Early application \\
\hline $\begin{array}{c}\text { Lazaroiu and } \\
\text { Roscia, } 2018 \text { [101] }\end{array}$ & $\begin{array}{l}\text { Smart metering \& } \\
\text { blockchains for } \\
\text { prosumers } \\
\text { Energy market trading } \\
\text { agent algorithm } \\
\text { communicates with } \\
\text { smart meters }\end{array}$ & $\begin{array}{l}\text { Balancing supply and } \\
\text { demand for unsteady } \\
\text { sustainable resource } \\
\text { supply }\end{array}$ & $\begin{array}{c}\text { Ensure security } \\
\text { Smart appliances in IoT } \\
\text { required }\end{array}$ & Case study \\
\hline Li et al., 2018 [102] & $\begin{array}{l}\text { Energy internet } \\
\text { Integrating diverse } \\
\text { producers and prosumers } \\
\text { by control center }\end{array}$ & $\begin{array}{l}\text { Energy production\& } \\
\text { consumption integrated } \\
\text { Asset investment \& } \\
\text { trading optimized } \\
\text { Information value added }\end{array}$ & $\begin{array}{l}\text { Market access and exit } \\
\text { mechanism } \\
\text { Reward \& punishment } \\
\text { mechanism to be } \\
\text { developed } \\
\text { Financing required }\end{array}$ & Conceptual stage \\
\hline $\begin{array}{l}\text { Marinopoulos et al., } \\
2018 \text { [103] }\end{array}$ & $\begin{array}{l}\text { Local energy } \\
\text { communities in smart } \\
\text { grids }\end{array}$ & $\begin{array}{l}\text { Regional/ local energy } \\
\text { communities link } \\
\text { prosumers and DSO }\end{array}$ & $\begin{array}{c}\text { Motivate DSO to integrate } \\
\text { local prosumer } \\
\text { communities }\end{array}$ & Early application \\
\hline $\begin{array}{l}\text { Pop et al., } 2018 \\
{[104]}\end{array}$ & $\begin{array}{l}\text { Blockchain mechanism } \\
\text { for energy flexibility. } \\
\text { Smart metering, smart } \\
\text { contracts with rewards \& } \\
\text { penalties, rules for } \\
\text { demand-supply } \\
\text { balancing in grid }\end{array}$ & $\begin{array}{l}\text { Prototype prove success } \\
\text { of matching demand and } \\
\text { supply } \\
\text { In future: flexible } \\
\text { peer-to-peer } \\
\text { decentralized energy } \\
\text { trading mechanism }\end{array}$ & $\begin{array}{l}\text { Limitations as grid level } \\
\text { have to be observed }\end{array}$ & Conceptual stage \\
\hline
\end{tabular}


Table 1. Cont.

\begin{tabular}{|c|c|c|c|c|}
\hline Author, Year & Technology & Advantages/Potentials & $\begin{array}{c}\text { Limitations/Development } \\
\text { Needs }\end{array}$ & $\begin{array}{l}\text { Applicability } \\
\text { Level }\end{array}$ \\
\hline $\begin{array}{l}\text { Samuel et al., } 2019 \\
\text { [105] }\end{array}$ & $\begin{array}{l}\text { Grid access mechanism } \\
\text { via blockchain enabling } \\
\text { differential privacy and } \\
\text { reputation scores, } \\
\text { aggregators coordinate } \\
\text { smart contract }\end{array}$ & $\begin{array}{l}\text { Proof of authority at } \\
\text { aggregator level enables } \\
\text { participation of small } \\
\text { prosumers }\end{array}$ & $\begin{array}{l}\text { Smart metering data } \\
\text { cannot be shared in } \\
\text { between households due to } \\
\text { privacy concern so } \\
\text { aggregator required }\end{array}$ & Conceptual stage \\
\hline $\begin{array}{l}\text { Schmidt et al., } 2018 \\
\text { [106] }\end{array}$ & $\begin{array}{c}\text { Short term energy } \\
\text { market, balancing power } \\
\text { auction, local flexibility } \\
\text { markets for DSO }\end{array}$ & $\begin{array}{c}\text { Flexibility markets result } \\
\text { in revenue increases in } \\
\text { simulation }\end{array}$ & & $\begin{array}{l}\text { Conceptual stage } \\
\text { (local grids exist) }\end{array}$ \\
\hline $\begin{array}{c}\text { Stevanoni, } 2018 \\
\text { [107] }\end{array}$ & $\begin{array}{l}\text { Industrial microgrids in } \\
\text { distribution networks }\end{array}$ & $\begin{array}{l}\text { Share locally produced } \\
\text { energy } \\
\text { Surplus is sold outside }\end{array}$ & $\begin{array}{l}\text { Communication and } \\
\text { operation costs, IT } \\
\text { technique }\end{array}$ & $\begin{array}{l}\text { Industrial micro } \\
\text { grids in application }\end{array}$ \\
\hline $\begin{array}{l}\text { Verma et al., } 2018 \\
\text { [108] }\end{array}$ & $\begin{array}{l}\text { Irish blockchain for P2P } \\
\text { energy trade, coalition } \\
\text { formation, double } \\
\text { auction }\end{array}$ & $\begin{array}{l}\text { Subsidiarity of local } \\
\text { communities }\end{array}$ & $\begin{array}{l}\text { Revenue/ cost distribution } \\
\text { Definition of adequate } \\
\text { trading model }\end{array}$ & $\begin{array}{l}\text { Ener Port project } \\
\quad \text { (prototype) }\end{array}$ \\
\hline $\begin{array}{l}\text { Wang et al., } 2019 \\
\text { [109] }\end{array}$ & $\begin{array}{l}\text { Blockchain based } \\
\text { individual P2P } \\
\text { interaction, day ahead } \\
\text { and hourly planning }\end{array}$ & $\begin{array}{l}\text { Seamless energy trade } \\
\text { also for separated } \\
\text { communities }\end{array}$ & $\begin{array}{l}\text { Potential malicious attacks } \\
\text { Malicious market operators } \\
\text { \& outsiders }\end{array}$ & $\begin{array}{l}\text { Prototype/ case } \\
\text { study }\end{array}$ \\
\hline $\begin{array}{l}\text { Wörner et al., } 2019 \\
\text { [110] }\end{array}$ & $\begin{array}{c}\text { Swiss blockchain } \\
\text { electricity market: } \\
\text { individual P2P price } \\
\text { determining and auction } \\
\text { algorithm }\end{array}$ & $\begin{array}{l}\text { Subsidiarity of local } \\
\text { communities } \\
\text { More efficient usage of } \\
\text { regenerative energy } \\
\text { resources }\end{array}$ & Centralized power market & $\begin{array}{l}\text { Prototype/ case } \\
\text { study }\end{array}$ \\
\hline Xu et al., 2021 [111] & $\begin{array}{l}\text { Energy bloc chain using } \\
\text { smart grid architecture }\end{array}$ & $\begin{array}{l}\text { Autonomous and } \\
\text { automated energy } \\
\text { trading to integrate small } \\
\text { decentral regenerative } \\
\text { sources }\end{array}$ & $\begin{array}{c}\text { Present fully and } \\
\text { semi-centralized electricity } \\
\text { markets }\end{array}$ & Conceptual stage \\
\hline $\begin{array}{c}\text { Zhang et al., } 2018 \\
\text { [112] }\end{array}$ & $\begin{array}{l}\text { Bidding process for } \\
\text { prosumers in microgrids } \\
\text { suing Bayesian game } \\
\text { technology }\end{array}$ & $\begin{array}{l}\text { Efficient matching of } \\
\text { supply \& demand }\end{array}$ & $\begin{array}{l}\text { Application technology for } \\
\text { large grids }\end{array}$ & Conceptual stage \\
\hline $\begin{array}{c}\text { Zhao et al., } 2019 \\
\text { [113] }\end{array}$ & $\begin{array}{c}\text { Blockchain for P2P } \\
\text { energy trading and share } \\
\text { Ev charging, U.S. Projects }\end{array}$ & $\begin{array}{l}\text { Blockchain enhances } \\
\text { information management } \\
\text { in IOT }\end{array}$ & $\begin{array}{l}\text { Local versions have to be } \\
\text { rolled out at larger scale }\end{array}$ & $\begin{array}{l}\text { Prototype/ case } \\
\text { study (U.S.) }\end{array}$ \\
\hline
\end{tabular}

The studies address diverse technologies, however, partly overlapping. A mind-map (Figure 3) illustrates the main development issues on the way towards flexibility grids, the studies address, and is useful to classify the discussion in the reminder of Section 3. 


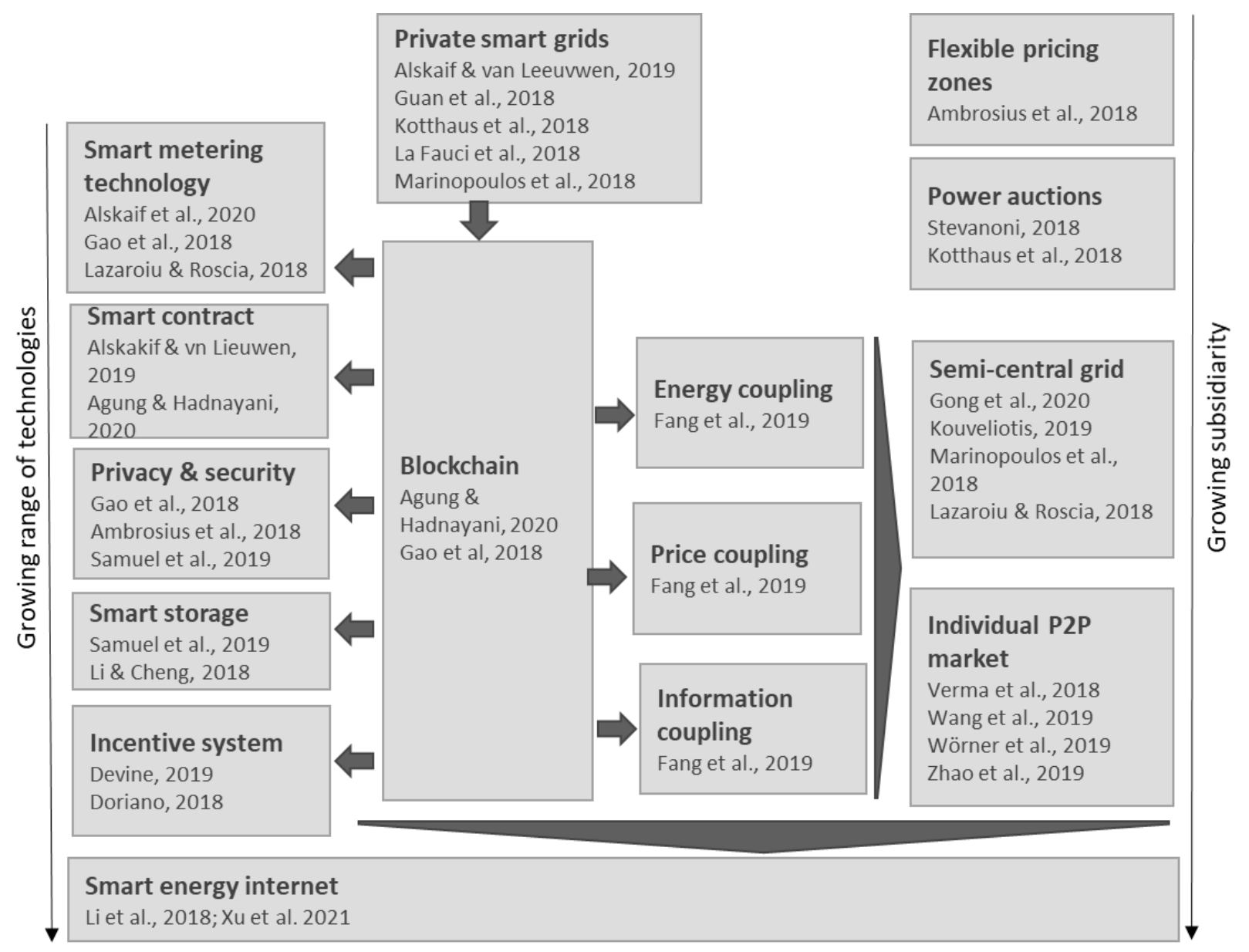

Figure 3. Mindmap classifying issues and stages of the development of flexibility grids.

The central section of Figure 1 classifies the blockchain technology as the pivotal technology on the way towards a fully subsidiary smart energy internet. The blockchain can take over three technological functions in the energy distribution system: energy coupling, price coupling and information coupling [89]. The left column of Figure 1 summarizes the main technologies to be developed to enable flexibility grids. The right column of Figure 1 illustrates different flexible pricing schemes addressed by the reviewed studies classified by order of growing subsidiarity of the grid participants from top to bottom in the chart. A growing range of blockchain related technologies allows increasing participant subsidiarity in the distribution system. The following textual analysis is structured according to the main items of the mind map, starting from its center, to address the key technology of blockchain, then discussing the left column of required technologies in the blockchain, and, finally, the right column of market concepts to which the blockchain technology is applicable.

\section{Blockchain Technology for Energy Allocation}

\subsection{The Blockchain Technology}

Blockchain is a broadly applicable distributed ledger technology enabling decentralized transactions and data management. The blockchain is a public and decentral online database which comprises a list of data and processes concerning a particular object in cryptographic code. The current status of transactions is stored with every participant in the transaction chain to the date of her transactions and follow up transactions are added to the list and are documented at all follow up users. The course of the transaction is, thus, validated and can be reconstructed later on, which prevents abuse and fraud [106]. 
Blockchains enable users to self-reliantly conclude smart contract that work automatically based on self-executing scripts. Smart contracts are electronic transaction protocols executing the terms of contracts in virtual space. All blockchain participants can view the contract operation course, while its content is coded cryptographically. Blockchains enable virtual market places for assets that can be limited in access to authorized peers. The traded assets can be traced concerning their origin by digital authentication certificates [114].

The blockchain technology is established for virtual currencies and the trading of diverse goods already and its potentials for energy trading [115-117] and distribution have first been explored in private smart grids [118-120]:

\subsection{Private Smart Grids-A First Step to Practicabiltiy}

Smart grids comprise an information and communication infrastructure, to get informed on demand and supply, a grid management system, to regulate access, and a control and protection system, to prevent excess loads [89]. Every grid participant represents a node in the blockchain network and can interact with every other participant [84]. Smart grids are capable of regulating access to the grid by assessing grid capacities and predicting loads and demand [121]. In diverse countries above all in China (more than 100 projects, the US, and Israel (300 local distribution networks), smart micro grids are used successfully to manage electricity production and consumption in islanded communities, campus, and hospitals [92]. The microgrid can take recourse to other larger grids in case these buffers are depleted or full, which would reduce transportation and administration efforts in transmission grids [122]. Microgrids are, thus, reconnected to the conventional public electricity grid to feed in surplus energy there and own supply in case of temporary local shortage [93]. A 2017 survey in Europe located 952 smart grid projects collaborating with DSO and municipalities as emerging stakeholders in the energy market already [98].

Motivations to utilize microgrids reach from ensuring autonomous power supply in remote areas, to an enhancement of electricity security and distribution standards [95]. Smart microgrids relying on regenerative resources are sustainable and avoid losses in the distribution grid by minimizing transportation distances. By diminishing the transaction costs of electricity interchange and distribution, smart microgrids save end-users costs and, at the same time, ensure transparency and security [85].

Privacy concerns in microgrids have been raised since participants have to disclose their usage habits to the community. Guan et al. [92], however, propose a standard to veil sensitive data by cryptographic protocols and pseudonyms, which change with every transaction.

\subsection{The Vision of Smart Energy Internet}

Smart microgrids have promoted the vision of a smart energy internet comprising all energy providers, consumers, and prosumers in a larger area, e.g., a country. Individual entities could be able to sell their self-produced electricity through a blockchain, and consumers could choose from the available offers [84].

The "energy internet" could be designed as a platform that connects local providers and consumers via a virtual control center. The "Energy + Internet" project of the Chinese government advances this technology, and 55 government-funded pilot projects have already been installed [97].

Via blockchain technology, a comprehensive virtual communication network comprising industrial machinery, but equally household appliances, could be devised, in which all participating entities could interchange their electricity consumption or supply based on a market mechanism [97]. 
According to Li et al. [97], China's vision is to transgress to a fully decentralized flexible energy market via the blockchain in future, a solution which will equally allow the frictionless integration of small prosumers disposing of decentral sustainable energy resources. Coordination between regions and, sustainable energy availability will improve. Load control will become easier. Consumers will be free to choose their energy providers and will be encouraged to opt for local communities, which would diminish transportation costs. The establishment of liberal energy markets would encourage private financing initiatives for grid expansion beyond the present government plan in China. If electricity distribution is reimbursed based on market prices, private financing will become an attractive investment.

\section{Technological Requirements and Standards for Blockchain-Based Flexibility Markets}

A range of novel technologies is required to establish a working energy blockchain: The systematic review retrieves the following issues and potential solutions discussed in academic research:

- $\quad$ Energy feed-in and consumption have to be measured and documented on-time at every consumer and provider by smart metering technologies.

- Smart contracts regulate user participation and contractual conditions on the energy blockchain.

- Prosumers Privacy and security concerns of have to be met.

- Energy storage capacities are required to buffer capacities and discharge the grid.

- Smart contract mechanisms are required to reliably organize feed-in and consumption conditions in the blockchain.

- Incentive systems have to be devised to motivate consumers and providers to consume energy in high load situations and feed-in energy when required.

The following major technological solutions are suggested to implement flexible distribution grids: smart metering, smart contracts, privacy \& security technology, smart storage, and market incentive mechanisms. These are discussed in detail in the following paragraphs.

\subsection{Smart Metering}

Smart meters are novel types of electricity meters using wireless technologies and report meter readings on-time to the energy provider on a blockchain, to allow time-based billing [90]. Smart meters display and document consumption and billing information to consumers via a home display or IT intersection. In a blockchain framework, smart meter data are collected, verified, and documented in the blockchain to organize electricity distribution and billing [90]. Smart metering systems regulate the activity of individual grid participants in an automated way depending on local facilities [123]. The smart meter can address diverse electric devices, e.g., electric cars or household appliances, and collects and mediates consumption and production data on the blockchain. The smart metering system is, thus, the basic interaction device between prosumers and the energy blockchain. Based on the smart meter information, predictions on consumption and production patterns are possible, which are useful for planning loads on the public grid [96]. Smart meters are fundamental to organize local flexibility markets and a blockchain-based automated electricity feed-in and consumption scheme.

\subsection{Smart Contract}

Smart contracts are IT functions that are activated on request and perform certain actions (e.g., electricity delivery, consumption, or payment for consumption) automatically as soon as the conditions for contract fulfillment are met. Smart contracts are documented in the blockchain and, thus, are immutable and are executed reliably [84]. 
To optimally manage the inflow of decentral energy resources on the distribution grid smart contracts, blockchain-based access control and coordination mechanisms are applied [90]. These enable prosumers and consumers to reduce their energy expenses and providers to maximize their revenues, while, at the same time, load on the grid is controlled. AlShakif and van Lieuwen [85] suggest a decentralized optimal power flow model, which coordinates the inflow and consumption of energy resources in the form of a blockchain script. The mathematical approach based on the Alternating Direction Method of Multipliers (ADMM) is tested in an Amsterdam microgrid. The smart contract serves as a virtual aggregator of the consumption and provision requests of grid participants, which are optimized by decentral algorithm-based blockchain accesses.

\subsection{Privacy and Security Concerns}

Electricity related transactions and payments on the web, which are implemented in a decentralized form, i.e., directly between diverse providers and consumers, via a blockchain, raise security- and privacy-concerns: Private data transferred to the blockchain can be abused, and consumer payments for electricity consumption are hard to control, particularly if several smart devices report their consumption on the blockchain selfreliantly. Every device risks manipulation by malicious actors [90].

Proof of stake algorithms limit and control access to blockchain networks to users contracting or providing electricity on the grid [88]. These are successfully used in bitcoin trading already and have to be adapted to electricity blockchains to ensure privacy and verify the transactions [84].

Gao et al. [90] apply cryptographic keys to control grid access and ensure confidentiality of consumers' transactions: Consumers obtain a private key for every blockchain transaction and retrieve a public key by the grid, to verify their identity. A third authenticator contract key is created in this communication process which is attached to the smart contract and used to encrypt the consumption reports. This mechanism ensures the smart contract against illegitimate intrusion.

Samuel et al. [124] suggest an interaction mechanism of differentiate privacy which keeps certain private data undisclosed, while consumers can - against a remunerationdecide to disclose consumption patterns via a communication protocol. Consumers with load adequate consumption, informing the blockchain on their consumption patterns, obtain cheaper contraction conditions in high-provision periods [100].

\subsection{Smart Storage}

The development of smart energy storage modules is crucial to increase the flexibility of grid feed-in and consumption. Excess electricity resources are stored in central heat or cold storage or battery storage systems until distribution [125].

The participating consumers and feeders would dispose of storage devices, e.g., local battery blocks or electric cars, to store electricity required on one or several days until grid conditions allow feeding in or contracting external resources [126]. Dispatching managers by micro-units could automatically organize the feed-in and retrieval of electricity from the grid so that a stable voltage level is maintained [127]. Decentral energy storage capacities will, at the same time, discharge larger grids and provide flexibility to integrate sustainable intermittent energy resources [97].

\subsection{Incentive Systems}

To discharge distribution grids and effectively match intermittent sustainable electricity supplies and demand incentive systems are required, which motivate consumers to move their consumption peaks to periods of high supply [106]. To ensure adequate incentives, smart contracts are designed to associate incentive and penalty rates to participants' usage patterns so that deviations from a grid-load adequate consumption are more expensive than conclusive behavior. Electronic mechanisms at the consumer (smart meters) are then adjusted so that flexible devices (e.g., washing machines) are operated under favor- 
able conditions preferably. Based on this algorithm and the pooled data from all consumers grid operators can then plan grid capacities and large supply units to meet consumption requirements. The approach has successfully been tested in microgrids already [88].

Devine et al. suggest an alternative incentive scheme based on an energy-backed token declining in value in time, which is applied to dispatch redundant energy on the web to decentral and self-organized consumers. The token ensures that consumers receive a temporary "voucher" for cheaper electricity contraction in redundance periods. Simulations prove a positive incentive effect [87].

\section{Market Solutions for Energy Distributions-Towards Growing Subsidiarity}

Based on blockchain technology and related frameworks market-solutions for electricity distribution allowing varying degrees of participant subsidiarity are suggested. The role of today's electricity providers and grid operators could change towards transaction enablers or bridging entities, which would increasingly take a coordinating rather than distribution function in the energy grid [106]. The following sections discuss possible market concepts by order of growing participant subsidiarity.

\subsection{Flexible Pricing Zones}

In a flexible pricing zone regime, different prices are assigned depending on consumption time and consumer-provider distance, for instance. Price assignment can be used to guide investment and production in the long run. Ambrosius et al. apply a welfaremaximizing multilevel mixed-integer nonlinear model, to determine welfare maximizing price zones under capacity restrictions. The study observes that with increasing numbers of price zones welfare is increased since matching supply and demand turns more effective [82].

Flexible pricing concepts are preconditional to motivate electricity consumers and suppliers to regulate feed-in and consumption of energy according to the conditions on the grid [128]. The definition of (temporary) fixed pricing zones reaches an improvement of supply-demand matching through the price mechanism but perfect matches are difficult, since the optimal price incentive switches as soon as supply or demand patterns change. Dynamic pricing schemes adaptive to electricity supply and demand at very short notice would be required to enhance the concept.

\subsection{Power Auctions}

Kotthaus et al. [93] suggest an auction market design to increase local subsidiarity, while, at the same time, grid stability is ensured in the present German distribution grid. DSO (distribution systems operators) should be the only admissible consumers of flexibility products, i.e., storage capacity or electricity. Both flexibilities should be offered via an online platform, and DSO decide on the price they pay for the flexibility. The online platform operator could administer several online trading platforms, each assigned to a certain territory. Cross territory flexibility trading could be possible if free grid facilities exist. The auction concept could be open to accredited prosumers, whose data are passwordprotected. Stevanoni et al. refine this scheme for microgrid access to distribution grids. Microgrid participants would indicate their consumption and feed-in prognosis for the coming period (day) to a single point of connection with the distribution network. The DSO would then decide whether and at which conditions they would accept the offered electricity [102]. Grid operators inform automated metering systems on the topical price and these could individually adapt feed-in or consumption to market conditions based on calculation routines [129]. 
This power auction's solution would encourage regional and enable cross-regional trade, while, at the same time, the limited capacities in transmission grids would be considered since DSO as monopolistic buyers of electricity would control grid inflows by their demand policy. The power auction model, however, does not empower electricity providers to self-reliantly offer their electricity in a liberal polypolistic market, which, in practice, would restrict prosumer feed-in and, in results, would discourage private investments in electricity generation.

\subsection{Semi-Central Transactive Grids}

Both above-discussed policy schemes-flexible pricing and power auctions-require smart metering but cope without blockchain technology since electricity distribution takes place according to previously agreed conditions and a demand prognosis. Semi-central transactive grids as suggested by the U.S. Department of Energy integrate blockchain technology to further flexibilize the trade of smaller market participants (flexible prosumers, microgrids, and energy communities or aggregators) with DSO. Further, a superior layer of blockchains could be used for TSO-DSO trading or the trading of DSO and TSO in the wholesale electricity market [94]. The community members could then freely decide on the amount of electricity they offer or receive and on the conditions at which they are ready to do this. Gong et al. [91] provide a technology to automatically consider framing conditions of the acceptance of decentral provider offers at the DSO level using an electronic bottomup negotiation mechanism based on a master-slave multichain. The system disposes of an additional security check to avoid grid overload and a dispatch management protocol.

Individual bidding mechanisms could be applied on microgrids to realize competitive prices [130]. Regenerative energy providers would submit competing offers and the provider offering the most attractive conditions for the consumers' requirements would be accepted. The direct trading between consumers and providers would avoid the transaction costs of regulating a hierarchical market and enable consumers to choose individually attractive offers. A game theory analysis shows that an optimum pricing level covering the costs of the provider would be reached [107].

The semi-central transaction market could be organized via smart blockchain contracts concluded between the consumers, the small-scale suppliers, and the DSO. The algorithm at the DSO level would coordinate inflow to the grid and distribution via smart meters installed at every market participant. Significant transaction cost savings of all community members ( $7.8 \%$ at the consumer and $20.8 \%$ at the DSO level) have been found in simulations based on the Ethereum network [94].

\subsection{Subsidiary Peer-to-Peer (P2P) Markets}

Subsidiary P2P markets trade quantities of energy or related services between different market partners based on the available network capacity only, without the obligatory coordination of a DSO [131]. The system operator is the technical responsible for the operationality of the blockchain market mechanism. Smart electricity markets comprise electricity consumers, prosumers (producers and consumers), and service providers or aggregators as equal participants [132]. Small consumers and prosumers would be free to bundle their demand in an aggregator group or offer electricity self-reliantly on a blockchain network [108].

New combinations of wireless internet communication and blockchain technology could be used to transmit information on free flexibilities even from remote locations and would, at the same time, allow all prosumers to interconnect their electronic devices through the internet of things [108].

Smart pricing concepts assign market prices to energy based on an on-time comparison of electricity supply and demand. Smart pricing concepts depend on decentral smart metering systems that assess and indicate the consumed or provided amounts at each grid participant [133]. Consumers would have to accept price fluctuations and demand-based schemes accordingly [96]. 
Flexible grid participants, disposing of adequate storage media do not depend on continuous electricity consumption or feed-in according to their on-time requirement but decide, when they take recourse to electricity on the grid [134]. Electric cars and shared charging piles would take an important buffering role [108]. Prices would then be adaptive to grid conditions, i.e., electricity is cheaper in periods of high inflow and low demand and more expensive for high demand and low inflow [135]. Electricity consumers and providers would be free to accept prices matched by the blockchain and participate in the trade [96]. The trading mechanism would be fully automatized by smart meters.

To structure energy provision a base-consumption, which is always accessible, and conditional consumption, which is retrieved only in case of redundant feed-in could be distinguished. Smart metering systems could inform the grid on present and planned consumption or feed-in, operate on time, and define consumption and load-depending tariffs. To stabilize grid infrastructure all consumers could be obliged to participate in this scheme of peak load smoothing, even if they do not dispose of storage media [136]. Dynamic allocation and pricing models would be informed by and could re- inform grid monitoring systems, which would anticipate planned consumption or feed-in based on decentral data. Possible smart metering and billing concepts have been suggested by electricity providers [137] and Bundesnetzagentur [125] before.

The liberal polipolistic P2P market presupposes a fully built flexible transmission grid and a comprehensive smart metering infrastructure. Semi-central grid solutions are required to realize a transition to fully flexible markets gradually with the development of adequate infrastructure. Initial private energy blockchain are in operation in the USA already for liberal P2P electricity trading among electric vehicles [108] and microgrids in remote communities in Switzerland [105].

Summing up the review- insights, a range of blockchain based technologies and market schemes adaptable to amend on Germany's present EEG regulation have been suggested. Financial and technical issues have to be integrated, to come to a comprehensive solution for the development of Germany's electricity market towards a more efficient scheme than the EEG 2017 provides.

\section{A Comprehensive Flexible Supply and Pricing Scheme for Europe's Electricity Market}

The following draft of an alternative flexibility market scheme for a regenerative electricity supply and distribution system takes into account both the technical and financial perspective to amend on the existing EEG 2017 framework and realize a Europe-wide solution to the regenerative electricity issue.

\subsection{Central Aims and Measures}

The scheme follows three central aims, which are: sustainability, subsidiarity, and flexibility.

Taking a market-based perspective the development targets of sustainability, subsidiarity, and flexibilization are realized by a simple pricing scheme, which is applicable for Europe as a whole, but can be adjusted according to the targets of each country. No further incentives of the subsidy-type are necessary.

As of today, the European spot market continuously indicates prices for electricity, in the style of a minutely stock indicator. Prices are indicated, one for regenerative electricity and one for conventional electricity, regenerative electricity, and comprises all energies that renew themselves and do not deplete [15]. Conventional electricity comprises electricity from all other resources, e.g., from nuclear and fossil sources. These spot market prices are the reference for trading electricity among all market participants.

Each country defines sustainability targets, i.e., timepoints at which certain shares of regenerative electricity from total electricity are realized, in the style of Germany's $\S$ 1 (1) EEG and ideally on an annual basis (in the following called target periods). Every consumer is obliged to buy the target share of regenerative electricity indicated by the government in her country, from the start of the target period. 
Market participants pay for utilizing the grid and grid operators individually define a grid fee by transportation distance and transported amount, which is added to the electricity price. Laws regulating grid fees prescribe the assignment of a distance and an amount-based price component only but do not fix grid fees. Prosumers are free to buy and sell to a provider, consumer or prosumer they desire. No further fees or costs are charged except national VAT.

Grid operators have to admit electricity from any provider and are authorized to charge a self-defined grid fee by amount and distance. To ensure grid stability, they are authorized to restrict inflow in situations of eminent grid instability according to the traffic-light principle described in Section 3.2 [118,138].

\subsection{Implementation of a Flexible Pricing Scheme Based on Smart Metering and Blockchain Technology}

The review has shown that flexible regional pricing schemes have got enormous potential to realign supply and demand in electricity markets. A Europe- or Germany-wide roll-out of flexible blockchain trading platforms, however, is prevented by limited DSO and TSO grid capacities. To implement the idea of a flexible regional pricing scheme, a digital platform to trade electricity and interchange grid capacities for supply and feed-in has to be designed under the control of DSO and TSO operators in the style of a semi-central transactive grid first, so that on the one hand market entry barriers for all-equally small and ecological—providers are minimized, while, at the same time, grid stability is ensured. Although this approach has been developed conceptually in diverse studies [91,94,107], its practical implementation across Germany or Europe has never been seriously considered.

The required platform has two purposes: First, it ensures that the legally required amount of regenerative energy is consumed. Second, the platform enables citizens to participate in the energy market by making their capacities available to the network operator. To fully develop its benefits, the platform has to answer the following three questions in any time point: (1) When is (2) which capacity available at (3) which point. The platform creates economic incentives, by providing a possible marketing option for all its participants to provide the required capacities and consume according to the available facilities. The platform has to be informed on all actors, the data basis, the data exchange, and the possible products at any time. This ideal can be realized by applying a blockchain framework for electricity trading in which all consumers, and suppliers, communities and grid aggregators can participate. The grid would be guided by DSO, who would admit offered electricity to their grid in so far as capacities are available and technically implemented by a blockchain agency, which would provide all market participants with smart metering technology and smart contracts regulating access. In this context, it should be noted that many practical issues have not yet been clarified yet, e.g., what happens if the highly available system is not available, and a fallback option is needed.

The legal conditions to implement a smart grid and smart metering system are in operation since 2020: Grid operators are authorized to take recourse to smart metering according to the Mess-Stellenbetriebsgesetz of 2016 [139]. The roll-out of this technology has taken plate in 2020 with the admission of the necessary hardware by BSI (Bundesamt für Sicherheit in der Informationstechnik) in 2020 [140].

The platform calculates the available amount of electricity offered and demand for every participating entity (household or business) at every second under the side condition that a certain amount of regenerative electricity has to be distributed following the legal conditions of the county. Starting from an initially arbitrarily defined base interchange price, the blockchain platform acts as a market maker allocates matching demand and offers prices for regenerative and conventional electricity in the way a market-making mechanism at financial exchanges has been working for decades. Market-making blockchain technologies have proven for the interchange of blockchain currencies [141]. At the level of industries, blockchain technology has equally proven for efficient and automated electricity distribution [142]. 
The market-making blockchain calculates for each consumer at every second, which electricity offer is optimal considering the offered price per kWh from the cheapest providers and the offered price per distance from the grid operator. Consumers' smart meters contract the required electricity from the blockchain, which assigns the price paid to the chosen and provider. Inversely, electricity can be sold at the best (highest) available price to consumers via the blockchain. The blockchain system calculates the matching consumers considering the grid distance tariff. For all calculations required, regenerative amounts are calculated and priced separately to conventional electricity amounts, while market prices for both electricity types form according to the described market mechanism only.

In effect, the base price for consumption, as well as the offered price for feed-in, increases when temporarily demand is higher than supply. Inversely, the interchange price lowers when supply is temporarily higher than demand. In effect the prices for regenerative electricity increase as long as supply is lower than legally required, which is a stable incentive system to increase regenerative electricity production.

\subsection{Blockchain and Smart Metering as Efficient and Ecological Incentive System}

The automated blockchain-based pricing mechanism creates a perfect incentive system for all market participants—consumers, providers, and grid operators-and, at the same time, maximizes ecological utility:

The blockchain system ensures that consumers buy regenerative electricity at a marketable price and in the amount prescribed by current national legislation, which meets the environmental targets of the economy. It ensures that regenerative electricity is adequately priced but still subject to a market pricing scheme.

The blockchain allocation considers the transportation distance in the pricing scheme and adds a grid distance fee, from each supplier to each consumer, which linearly depends on the distance between the two units. The grid fee is assigned to the provider of the electricity lines, i.e., grid operators. By charging the distance the system "punishes" long transportation lanes and rewards short distance supply-chains, which reduces required long-distance capacities and encourages (cheaper) local low-to medium- voltage and shortdistance electricity transportation. Short distance transportation reduces transportation losses and enhances price efficiency and ecological sustainability further.

Using the blockchain for choosing a provider, consumers decide on the cheapest electricity and transportation package to cover their electricity demand. If consumer devices are connected to the smart metering system, the smart meter directs consumption so that it takes place during a low price period (e.g., by night). Consumers are motivated to invest in household battery storage systems, to be able to change electricity, when prices are low. Consumers then contract at the cheapest possible total price for electricity, including transportation. This mechanism motivates suppliers to offer at a marketable price to sell electricity in the market.

The system of distance-based grid pricing favors local production since even higher unit prices for locally generated electricity are acceptable when distance fees are high. Remote providers (e.g., large power plants) can still compete at lower prices if they cooperate with transmission system operators and offer consumers an attractive market price for the complete package. Applying market prices, the natural monopolies of the distribution networks obtain new opportunities to improve their scope of application.

\subsection{Macroeconomic Impact of a Flexible Pricing Scheme}

This Europe-wide supply and pricing scheme provides optimal incentives for all market participants to switch to regenerative energies and buy from local providers.

At the beginning of the first planning, national regenerative energy development targets are defined, so that an addition of regenerative energy sources is necessary to cover the demand, development targets are above the initial supply. Since consumers are obliged to buy the target share of regenerative energy, the demand for these sustainable resources is above the supply, and the price for regenerative energy increases. This scheme, at the 
same time, motivates consumers to reduce their consumption or self-produce regenerative energy since initially the prices for regenerative energy are rather high. High prices, however, make investments in regenerative energies profitable, which induces prosumers and commercial providers to install regenerative plants and develop new technologies for regenerative energy generation. At the end of target period 1, the required share of regenerative energies is tightened by the government equally for every consumer in each country, for period 2 to incentivize further regenerative energy investments.

The following chart (Figure 4) summarizes the essential components of the drafted innovative supply and pricing scheme for Europe's electricity market.

\section{FLEXIBLE, SUBSIDIARY ELECTRICITY SUPPIY \& DISTRIBUTION SCHEME FOR EUROPE}

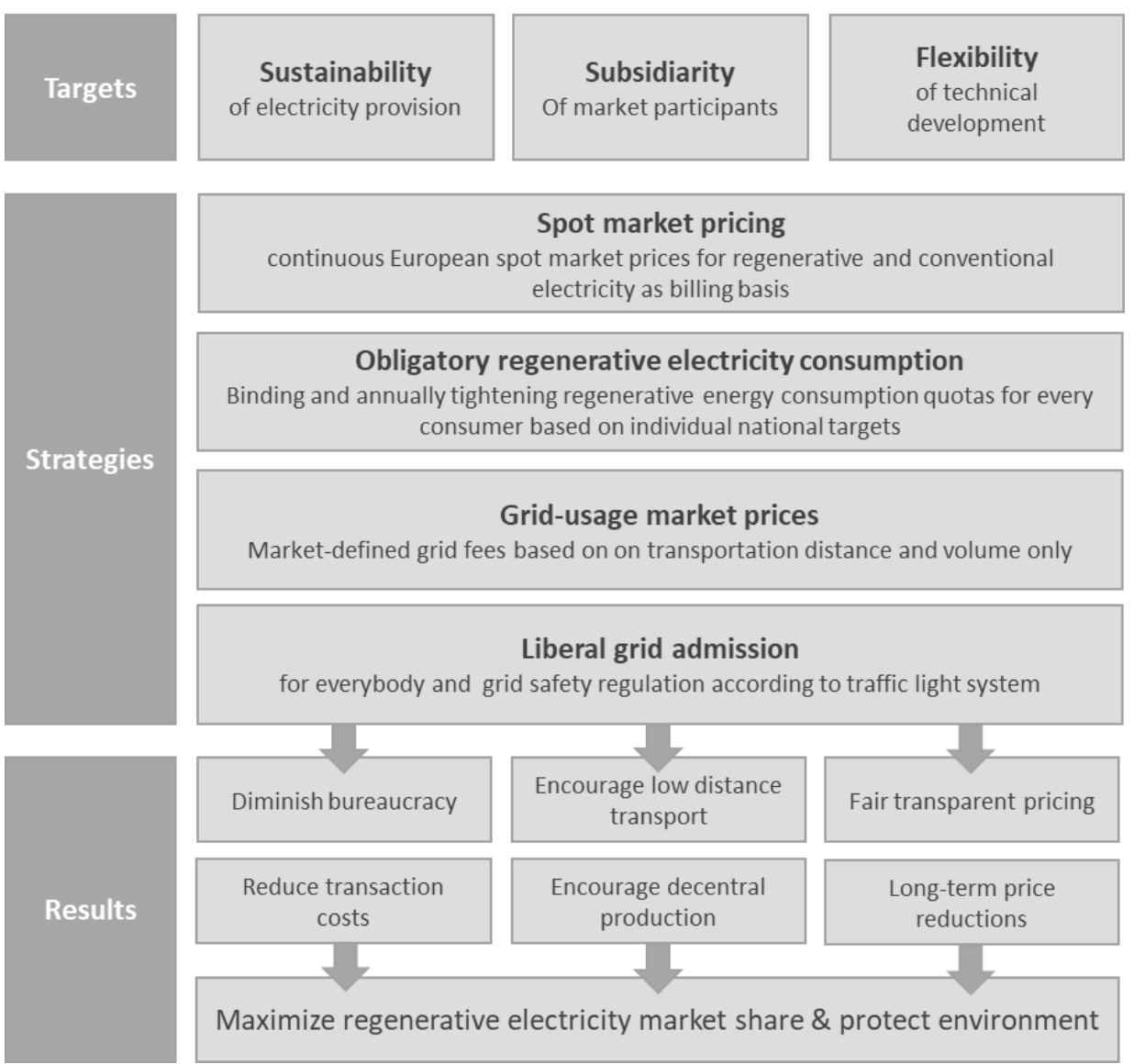

Figure 4. Summary of the essential components of the innovative supply and pricing scheme.

To date, four major impediments hamper the rapid implementation of the suggested flexible regional market scheme in Germany. These are sticky large supply structures, inflexible multilevel contract systems, fixed pricing agreements, and mental fears concerning the marketability of regenerative resources.

\subsection{Sticky Large Supply Structures}

Established structures in Germany's electricity sector are at odds with a cellular flexible approach as designed in this study. Traditionally, the German electricity grid has been designed in a hierarchical way and is a compact compound of few large energy producers [143]. his structure is rooted in the classical tradition of energy production in big nuclear or coal-fired power plants, which necessarily are controlled by large corporations. The switch of Germany's energy supply from fossil and atomic fuels to regenerative resources, however, has initiated a reorganization of these overcome structures. By 2015, 
the largest German providers covered a market share of $38 \%$ only (down from $0 \%$ in the early 2000s). Regenerative resources can effectively be generated decentrally in wind and PV plants. These technologies offer themselves for the application by private providers or small businesses since investment and operation costs by energy unit are moderate and the ecological impact of the units is low (as compared to large power plants). Germany requires further restructuring of its energy production and distribution sector from large centralized to small decentral providers [144].

Although the EEG 2017 basically obliges grid operators to connect local plants to the grid [21], the present design of the EEG 2017 reimbursement scheme curtails the contribution of decentral entities by bureaucratic structures, that are manageable by large energy providers only. Access restrictions to the market tender scheme prevent those producers below $750 \mathrm{~kW}$ for photovoltaic and $150 \mathrm{~kW}$ for biomass participate in the market at all at cost-covering conditions. In this scheme, small producers keep the electricity they produce in their entity which causes losses for local storage or reduces the utilization of available local production capacities. The obligation of producers from $750 \mathrm{~kW}$ to contribute to EEG 2017 demotivates private investments in regenerative energies.

\subsection{Inflexible Multilevel Contract Systems}

The present electricity provision scheme is based on multiple and hierarchically structured contract relationships, which are inadequate to the direct marketing of electricity between a large number of equal participants. To date, consumers dispose of a (fixed-price) delivery agreement with electricity providers, which includes grid utilization and a metering agreement with the grid operator. Electricity providers dispose of fixed provider framing agreements with regional grid operators. These dispose of a grid connection and utilization contracts with transmission system operators [52]. Fees, taxes, and apportionment are raised on the electricity price by the government and redistributed among the providers depending on their balance reports. This concept is inflexible for a smart metering system with free grid access for all grid participants.

\subsection{Fixed Pricing}

Under the present EEG scheme in Germany, electricity prices are not flexible to the demand and supply situation. Households are charged a price per kWh. Sometimes a night tariff is agreed on, but the actual situation on the grid is not reflected in the price [145]. This system is convenient since consumers do not have to assess when to consume energy. Providers do not have to plan prices but calculate fixed annual revenues from long-term contracts. However, this system is inadequate to a market in electricity from intermittent regenerative energies. Under a fixed-price scheme, consumption follows the life and work pattern of consumers, while regenerative energy inflow follows seasonal and weatherrelated conditions. Coordination of supply and consumption requires the adaptation of consumption patterns. The EEG 2017 scheme, however, does not motivate to adapt consumption to grid loads.

Regional flexibility markets, work out only if grid loads are priced, which transfers the burden on grid participants, i.e., consumers and feeders on the grid. These can influence the burden they have to bear by their actual behavior. Smart metering systems enable grid operators to guide user behavior and supervise and predict utilization habits, which is pre-conditional to adapt grid inflows and in the long-run grid size. Adequate technologies exist for the interaction of TSO and DSO but have not yet been implemented for consumers in DSO grids at a large scale [131]. 


\subsection{Fears Concerning the Marketability of Regenerative Energies}

Critics of a liberalization of electricity markets, fear that regenerative energies in Germany are not competitive as compared to cheap coal, gas and nuclear energy from other European countries [146]. The EEG 2017 (German regenerative energy law) regulation, it is argued, provides a reliable calculation basis for wind and solar plants, since the amounts and basic feed-in prices are defined by government. Under the protection of EEG, novel technologies which are not marketable yet, would develop towards a stable basis [147]. While government is obliged to public welfare, market is not, Felber [148] argues. Government subsidies for regenerative energies ensure that $\mathrm{CO}_{2}$ emissions diminish reliably and Germany contributes to sustainable global development [149].

Developments in other countries, however, prove that regenerative energies thrive without subsidies.

A merit order effect is observed for the feed-in of regenerative electricity in European electricity markets: Regenerative suppliers offer lower energy prices in the European stock market than their conventional competitors, which puts them in a market leading position [150]. In Italy, regenerative energies account for a wholesale price decrease by 2.3 to $4.2 € / \mathrm{MWh}$ [151]. Equally in Australia, regenerative energies crowd out fossil fuels in liberally priced electricity spot markets. Regenerative energy can be offered at very cheap prices, since the fixed costs of operation are much lower than for gas, oil and coal fired plants [152]. Regenerative electricity pushes conventional electricity out of the market due to lower tender offers. If these cost savings are handed down to consumers, regenerative electricity is available at much cheaper prices than presently in Germany, and a win-win situation is provided for consumers and the environmental results.

Germany's present policy, however, prevents that this positive outcome is realized: German regenerative producers do not have to compete in this market due to the EEG 2017 price assignment [139] scheme and subsidized by government have no incentive to improve their production scheme [153]. Prices remain high since there is no necessity for German regenerative industries to purport their position in the spot market [154]. While, initially, German regenerative providers enjoyed an advantage due to the additional gratifications, in the long run, German providers could lose in comparative efficiency on European competitors who have to compete in the liberal market [155].

\section{Conclusions}

The present condition of the German energy grid and the pricing scheme established by the German government impairs the development of a market for regenerative energy. A restructuring of Germany's and Europe's energy supply and pricing scheme according to the suggestions of Section 4 is urgent to meet the targets for a sustainable redesign of Germany's and Europe's electricity sector. Of course, this is not done in one day, since significant restructuring processes have to be planned and implemented. The following sections develop policy suggestions to step-by step progress to a flexible and regional electricity distribution and pricing scheme. Study limitations and further research requirements are outlined.

\subsection{Policy Suggestions to Implement Regional Flexibility Markets in Germany}

To switch from the scheme of centralized electricity provision by large market-dominating electricity suppliers to a system of regional subsidiarity of procurement, consumers have to be encouraged to produce electricity for self-consumption at first and step-by-step build-up capacities for delivering energy on the grid. The obligation of PV plants from $10 \mathrm{~kW}$ to pay an EEG 2017 apportionment according to $\S 62$, even if the generated electricity is only self-consumed, is certainly the wrong message and demotivates small businesses and private individuals to invest in regenerative energy production. This obligation should be abolished at once.

Smart metering systems are preconditional to transgress to a scheme of flexibility markets [156]. To motivate a possibly large number of households and businesses to invest 
in smart meters, energy providers should be encouraged to offer time and amount-based tariffs to consumers that dispose of smart metering technologies. As soon as a broad number of consumers dispose of smart meters, providers and grid operators obtain better control of grid inflows and consumption, which enables them to reorganize grid structures in a targeted way, e.g., reinforce trains of high feed-in and consumption. Since grid operators and providers benefit from the smart metering technology, they could support consumers' investment in the system financially.

The collaboration of transmission and district system operators has to be improved to realize a comprehensive grid structure without this strict division of authorities across Europe in the long run. A first step could be to encourage German DSO and TSO to define a transmission fee based on distance and volumes to cover the cost of the necessary future grid investments. The strict cost regulations as provided by EEG 2017 [53] should be abolished and a marketable rate should be found in a consortium of grid stakeholders rather than by external lawmakers. This grid tariff design could be gradually be rolled out to other European partner countries to allow the participation of foreign grid operators and regenerative providers in the German supply system. This means that $\S 5$ of EEG 2017 should be modified to ease the access of providers in neighboring countries.

Concerted action at the level of the European Energy exchange is required to develop a market price mechanism open for all market participants. This requires first assign two electricity spot rates: a regenerative and a conventional rate. Both rates should be published minutely in the way electricity futures are reported as of now. If minutely pricing of both electricity types is available the EEG and energy laws in other European countries should be changed so that providers can bill based on this rate optionally at first, while the EEG feed-in tariffs are still available as a second alternative. The German tendering system could be sopped at once, as soon as spot market prices can substitute tender prices.

Finally, a Europe-wide agreement on the individual sustainability targets of the partner state by year would have to be realized. Countries could participate in the European electricity network as soon as a law on sustainable electricity provision targets has been ratified. At that stage, the self-reliant European market concept could start in the participating countries.

The joint action of the member states of the European Union, energy producers, and grid operators could step by step realize a market concept for regenerative electricity, which leads to a Europe-wide accomplishment of comprehensive sustainability targets. This eager objective could be realized with few regulations and is open to a nation-specific timeline. Urgent action is required to ensure Germany's and Europe's energy security base on regenerative resources.

\subsection{Study Limitations and Further Research Needs}

Based on a critical analysis of the present German EEG 2017 electricity allocation scheme, and a systematic review of academic research and practitioner studies in regional flexibility markets this study has drafted a conceptual design for a market-oriented Europewide energy supply and pricing scheme. It would ease the achievement of sustainable electricity production standards across the European Union. As compared to the German EEG 2017, the approach is more liberal and flexible. It effectively uses market forces to enhance the attractiveness of regenerative resources for energy generation and a demandbased pricing scheme. As compared to the existing framework is saves transaction and supervision costs for all market participants and in the long run results in lower regenerative energy prices and regenerative electricity quotas of 80 to $100 \%$.

Still, the study does not provide a system ready for application but remains conceptual. Many more details have to be considered to implement the draft. The EEG has to be fundamentally redesigned, and European agreements on grid usage and the access of electricity providers to national markets have to be found. Grid infrastructure has to be developed and smart metering systems have to be installed for the majority of consumers. 
Liberalizing the European energy market will meet the resistance of diverse powerful stakeholder groups: Under EEG 2017, the German government takes in more than half of the turnovers from electricity consumption in the form of levies, fees, and taxes, while the new system would reduce this income to the VAT [67].

Large energy providers today account for about $80 \%$ of Germany's energy market. Decentralization of energy production would redistribute production capacities to small businesses and private investors. Both stakeholders are likely to raise concerns about the draft which counters their financial interests.

The concept for a flexible market-price electricity supply and distribution system so far is purely conceptual. Empirical studies quantifying the factual impacts of the ideas laid out here are outstanding and probably will reveal the need for refinement and development of the concepts. Constructive discussions on energy market liberalization are indispensable to advance technological innovations and market-adequate pricing to the benefit of a sustainable electricity economy.

Finally, the safety measure for grid operators is now conceptual, as well, and needs to be investigated further. Business processes on how the capacities can be commercialized need to be developed. Uniform processes for the transmission between the different grid status to another, and, hereby, the rebound effect needs to be considered. And a standardization for the capacity products is needed to simplify the processes.

Author Contributions: Conceptualization, T.R., P.T. and B.K.; methodology, T.R., P.T. and B.K.; software, T.R.;validation, T.R.; formal analysis, T.R.; investigation, T.R.; resources, T.R.; data curation, T.R.; writing-original draft preparation, T.R.; writing-review and editing, T.R., P.T. and B.K.; visualization, T.R.; All authors have read and agreed to the published version of the manuscript.

Funding: This study was funded by the Baden-Württemberg Ministry of Science, Research and Arts and Offenburg University of Applied Sciences. More information at https:/ /www.dene.uni-freiburg.de/.

Conflicts of Interest: The authors declare no conflict of interest.

\section{References}

1. Michaelides, E.E.S. Environmental and ecological effects of energy production and consumption. In Alternative Energy Sources; Springer: Berlin/Heidelberg, Germany, 2012; pp. 33-63.

2. Denning, R.; Mubayi, V. Insights into the societal risk of nuclear power plant accidents. Risk Anal. 2017, 37, 160-172. [CrossRef]

3. Khodzhiev, A.M. Recycling nuclear wastes to change the pollution problem. Научный Альманах 2019, 11, $183-186$.

4. Anderson, T.R.; Hawkins, E.; Jones, P.D. $\mathrm{CO}_{2}$, the greenhouse effect and global warming: From the pioneering work of Arrhenius and callendar to today's earth system models. Endeavour 2016, 40, 178-187. [CrossRef] [PubMed]

5. King, A.D. The drivers of nonlinear local temperature change under global warming. Environ. Res. Lett. 2019, 14, 064005. [CrossRef]

6. Alfieri, L.; Dottori, F.; Betts, R.; Salamon, P.; Feyen, L. Multi-model projections of river flood risk in Europe under global warming. Climate 2018, 6, 6. [CrossRef]

7. Huang, P. Time-varying response of ENSO-induced tropical Pacific rainfall to global warming in CMIP5 models. Part I: Multimodel ensemble results. J. Clim. 2016, 29, 5763-5778. [CrossRef]

8. De Siqueira, E.C.V.; da Luz, C.K. Contextualizing environmental migration: The gap between the legal nature of refuge and environment during the age of global warming and natural catastrophes. Revista de Direito Econômico e Socioambiental 2018, 9 , 125-141. [CrossRef]

9. Ash, K.; Obradovich, N. Climatic stress, internal migration, and Syrian civil war onset. J. Confl. Resolut. 2020, 64, 3-31. [CrossRef]

10. Selby, J.; Dahi, O.S.; Fröhlich, C.; Hulme, M. Climate change and the Syrian civil war revisited. Political Geogr. 2017, 60, 232-244. [CrossRef]

11. EHA. Strommix in Deutschland: Rekordhoch für Erneuerbare Energien. 2020. Available online: https://www.eha.net/blog/ details/strommix-in-deutschland.html (accessed on 14 April 2021).

12. Statista. Braunkohleförderung in Deutschland in den Jahren von 1990 bis 2019. Available online: https://de.statista.com/ statistik/daten/studie/156258/umfrage/braunkohlefoerderung-in-deutschland-seit-1990/ (accessed on 15 April 2020).

13. BMU (Bundesministerium für Umwelt, Naturschutz und nukleare Sicherheit). Verfassung und Gesetze. Available online: https:/ / www.bmu.de/themen/atomenergie-strahlenschutz/nukleare-sicherheit/rechtsvorschriften-technische-regeln/ grundgesetz-atomgesetz/\#: \{\}:text=AtG\%2DNovelle\%2C\%20die\%20die\%20Beendigung,Deutschland \%20bis\%20sp \%C3\%A4 testens \%20Ende \%202022 (accessed on 14 April 2021). 
14. Die Bundesregierung. Energiekonzept. 2010. Available online: https://www.bundesregierung.de/breg-de/themen/ energiewende/energiekonzept-614722 (accessed on 8 August 2020).

15. EEG. Gesetz für den Ausbau erneuerbarer Energien (ErneuerbareEnergien-Gesetz-EEG 2017). §1 (2). 2020. Available online: http://www.gesetze-im-internet.de/eeg_2014/EEG_2017.pdf (accessed on 5 August 2020).

16. EEG. Gesetz für den Ausbau erneuerbarer Energien (ErneuerbareEnergien-Gesetz-EEG 2017). §4. 2020. Available online: http://www.gesetze-im-internet.de/eeg_2014/EEG_2017.pdf (accessed on 5 August 2020).

17. Bundesregierung der Bundesrepublik Deutschland. Das Energiekonzept 2050. Available online: https://www.bundesregierung. de/resource/blob/997532/778196/8c6acc2c59597103d1ff9a437acf27bd/infografik-energie-textversion-data.pdf?download=1 (accessed on 5 August 2020).

18. Fraunhofer. Energiekonzept 2050. Eine vision für ein nachhaltiges Energiekonzept auf Basis von Energieeffizienz und 100\% erneuerbaren energien. Erstellt vom Fachausschuss “Nachhaltiges Energiesystem 2050" des ForschungsVerbunds Erneuerbare Energien. 2010. Available online: https://www.fvee.de/fileadmin/politik/10.06.vision_fuer_nachhaltiges_energiekonzept.pdf (accessed on 5 August 2020).

19. Batrancea, L. An econometric approach regarding the impact of fiscal pressure on equilibrium: Evidence from electricity, gas and oil companies listed on the New York stock exchange. Mathematics 2021, 6, 630. [CrossRef]

20. Batrancea, I.; Batrancea, L.; Maran Rathnaswamy, M.; Tulai, H.; Fatacean, G.; Rus, M.-I. Greening the financial system in USA, Canada and Brazil: A panel data analysis. Mathematics 2020, 8, 2217. [CrossRef]

21. EEG. Gesetz für den Ausbau erneuerbarer Energien (ErneuerbareEnergien-Gesetz-EEG 2017). §2 (1), (2) and (3). 2020. Available online: http:/ / www.gesetze-im-internet.de/eeg_2014/EEG_2017.pdf (accessed on 5 August 2020).

22. Korte, K.; Gawel, E. Stromnetzinvestitionen und anreizregulierung_Problemfelder und lösungsansätze. Wirtschaftsdienst 2015, 95, 127-134. [CrossRef]

23. EEG. Gesetz für den Ausbau erneuerbarer Energien (ErneuerbareEnergien-Gesetz-EEG 2017). §3 Nr 4. 2020. Available online: http:/ / www.gesetze-im-internet.de/eeg_2014/EEG_2017.pdf (accessed on 5 August 2020).

24. EEG. Gesetz für den Ausbau erneuerbarer Energien (ErneuerbareEnergien-Gesetz-EEG 2017). §23. 2020. Available online: http:/ / www.gesetze-im-internet.de/eeg_2014/EEG_2017.pdf (accessed on 5 August 2020).

25. EEG. Gesetz für den Ausbau erneuerbarer Energien (ErneuerbareEnergien-Gesetz-EEG 2017). §7 and §11. 2020. Available online: http:/ / www.gesetze-im-internet.de/eeg_2014/EEG_2017.pdf (accessed on 5 August 2020).

26. EEG. Gesetz für den Ausbau erneuerbarer Energien (ErneuerbareEnergien-Gesetz-EEG 2017). §12. 2020. Available online: http:/ / www.gesetze-im-internet.de/eeg_2014/EEG_2017.pdf (accessed on 5 August 2020).

27. EEG. Gesetz für den Ausbau erneuerbarer Energien (ErneuerbareEnergien-Gesetz-EEG 2017). §8. 2020. Available online: http:/ / www.gesetze-im-internet.de/eeg_2014/EEG_2017.pdf (accessed on 5 August 2020).

28. EEG. Gesetz für den Ausbau erneuerbarer Energien (ErneuerbareEnergien-Gesetz-EEG 2017). §9. 2020. Available online: http:/ / www.gesetze-im-internet.de/eeg_2014/EEG_2017.pdf (accessed on 5 August 2020).

29. EEG. Gesetz für den Ausbau erneuerbarer Energien (ErneuerbareEnergien-Gesetz-EEG 2017). §24. 2020. Available online: http:/ / www.gesetze-im-internet.de/eeg_2014/EEG_2017.pdf (accessed on 5 August 2020).

30. EEG. Gesetz für den Ausbau erneuerbarer Energien (ErneuerbareEnergien-Gesetz-EEG 2017). §30. 2020. Available online: http:/ / www.gesetze-im-internet.de/eeg_2014/EEG_2017.pdf (accessed on 5 August 2020).

31. EEG. Gesetz für den Ausbau erneuerbarer Energien (ErneuerbareEnergien-Gesetz-EEG 2017). §32. 2020. Available online: http:/ / www.gesetze-im-internet.de/eeg_2014/EEG_2017.pdf (accessed on 5 August 2020).

32. EEG. Gesetz für den Ausbau erneuerbarer Energien (ErneuerbareEnergien-Gesetz-EEG 2017). §34. 2020. Available online: http:/ / www.gesetze-im-internet.de/eeg_2014/EEG_2017.pdf (accessed on 5 August 2020).

33. Umwelt Bundesamt. Erneuerbare Energien in Deutschland. 2020. Available online: https://www.umweltbundesamt.de/sites/ default/files/medien/1410/publikationen/2020-04-03_hgp-ee-in-zahlen_bf.pdf (accessed on 6 August 2020).

34. Umwelt Bundesamt. Erneuerbare Energien in Deutschland. 2020, p. 9. Available online: https://www.umweltbundesamt.de/ sites/default/files/medien/1410/publikationen/2020-04-03_hgp-ee-in-zahlen_bf.pdf (accessed on 6 August 2020).

35. Umwelt Bundesamt. Erneuerbare Energien in Deutschland. 2020, p. 8. Available online: https://www.umweltbundesamt.de/ sites/default/files/medien/1410/publikationen/2020-04-03_hgp-ee-in-zahlen_bf.pdf (accessed on 6 August 2020).

36. Elsland, R.; Boßmann, T.; Hartel, R.; Gnann, T.; Genoese, M.; Wietschel, M. Analysis of structural changes of the load profiles of the German residential sector due to decentralized electricity generation and e-mobility. In Sustainability in Energy and Buildings; Springer: Berlin/Heidelberg, Germany, 2013; pp. 71-84.

37. Umweltbundesamt. Nutzung von Flüssen: Wasserkraft. 2019. Available online: https://www.umweltbundesamt.de/themen/ wasser/fluesse/nutzung-belastungen/nutzung-von-fluessen-wasserkraft\#wasserkraftnutzung-global (accessed on 6 August 2020).

38. Fachagentur Windenergie an Land. Ausbausituation der Windenergie an land im Frühjahr 2019. 2019. Available online: https:/ / www.fachagentur-windenergie.de/fileadmin/files/Veroeffentlichungen/Analysen/FA_Wind_Zubauanalyse_Windan-Land_Fruehjahr_2019.pdf (accessed on 6 August 2020).

39. NDR. Bau von Windkraftanlagen Bricht Drastisch Ein. 2020. Available online: https://www.ndr.de/nachrichten/info/Bau-vonWindkraftanlagen-bricht-drastisch-ein, windkraftanlagen114.html (accessed on 5 August 2020). 
40. Offshore-windindustrie. de. News rund um die Offshore-Windenergie. 2020. Available online: http://www.offshorewindindustrie.de/ (accessed on 6 August 2020).

41. Meister, T. Der Ausbau von offshore-windparks in Deutschland aus einer innovationsperspektive. Raumforschung Raumordnung Spat. Res. Plan. 2018, 76, 19-33. [CrossRef]

42. Iwr-Start. BNetzA Juni-Ausschreibung: Flaute bei Wind hält an-Solar deutlich überzeichnet. 2020. Available online: https: / / www.iwr.de/news.php?id=36804 (accessed on 6 August 2020).

43. Alexopoulos, S.; Hoffschmidt, B. Solar tower power plant in Germany and future perspectives of the development of the technology in Greece and Cyprus. Renew. Energy 2010, 35, 1352-1356. [CrossRef]

44. TEnnet. Making the Connection. Integrated Annual Report 2014. Tennet Holding B.V. Available online: https://www.tennet.eu/ fileadmin/user_upload/Company/Investor_Relations/Annual_Report/TenneT-AR14_UK.pdf (accessed on 8 February 2020).

45. Weber, F.; Jenal, C. Gegen den Wind: Konfliktlinien beim Ausbau erneuerbarer Energien in Großschutzgebieten am Beispiel der Windenergie in den Naturparken Soonwald-Nahe und Rhein-Westerwald; Verlag der ARL-Akademie für Raumforschung und Landesplanung: Hannover, Germany, 2018; pp. 217-249.

46. EDSO (European Distribution System Operators for Smart Grids). Future-Ready, Smarter, Electricity Grids. 2018. Available online: https:/ / www.edsoforsmartgrids.eu/wp-content/uploads/brochure (accessed on 6 August 2020).

47. Kerber, G. Aufnahmefähigkeit von Niederspannungsverteilnetzen für die Einspeisung aus Photovoltaikkleinanlagen. Ph.D. Thesis, Technische Universität München, München, Germany, 2010.

48. Photovoltaik4all. Aktuelle EEG Vergütungssätze für Photovoltaikanlagen 2021. 2020. Available online: https://www. photovoltaik4all.de/aktuelle-eeg-verguetungssaetze-fuer-photovoltaikanlagen-2017 (accessed on 6 August 2020).

49. WINDMONSTER.DE_Einspeisevergütung für Windenergie. Einspeisevergütung. 2012. Available online: https://www. windmonster.de/?Die_Fakten_Einspeiseverguetung\#: \{\}:text=Grundverg $\%$ C3\%BCtung\%20f\%C3\%BCr\%20Strom $\% 20$ aus $\%$ 20Windkraftanlagen, \%2C02\%20Cent\%2FkWh\%20Grundverg\%C3\%BCtung. (accessed on 6 August 2020).

50. Windbranche. de. Neowa setzt bei WEA-Rückbauprojekten auf DIN-Standards. 2020. Available online: https://www. windbranche.de/news/nachrichten/artikel-36888-neowa-setzt-bei-wea-rueckbauprojekten-auf-din-standards (accessed on 6 August 2020).

51. Umwelt Bundesamt. Zu geringe Recyclingkapazitäten für Rückbau von Windenergieanlagen. 2020. Available online: https: //www.umweltbundesamt.de/presse/pressemitteilungen/zu-geringe-recyclingkapazitaeten-fuer-rueckbau-von (accessed on 6 August 2020).

52. Frantál, B. Have local government and public expectations of wind energy project benefits been met? Implications for repowering schemes. J. Environ. Policy Plan. 2015, 17, 217-236. [CrossRef]

53. Masurowski, F.; Drechsler, M.; Frank, K. A spatially explicit assessment of the wind energy potential in response to an increased distance between wind turbines and settlements in Germany. Energy Policy 2016, 97, 343-350. [CrossRef]

54. EEG. Gesetz für den Ausbau erneuerbarer Energien (ErneuerbareEnergien-Gesetz-EEG 2017). §8-§10. 2020. Available online: http:/ / www.gesetze-im-internet.de/eeg_2014/EEG_2017.pdf (accessed on 5 August 2020).

55. Agora. Energiewende: Was bedeuten die neuen Gesetze? 2020. Available online: https://www.agora-energiewende.de/ fileadmin2/Projekte/2016/EEG-FAQ/Agora_Hintergrund_FAQ-EEG_WEB.pdf (accessed on 5 August 2020).

56. EEG. Gesetz für den Ausbau erneuerbarer Energien (ErneuerbareEnergien-Gesetz-EEG 2017). §62. 2020. Available online: http:/ / www.gesetze-im-internet.de/eeg_2014/EEG_2017.pdf (accessed on 5 August 2020).

57. Zander, W.; Rosen, U.; Nolde, A. Regulierung, flexibilisierung und sektorkopplung. In Erstellt im Auftrag des Bundesministeriums für Wirtschaft und Energie; Federal Ministry of Economics and Technology: Berlin, Germany, 2018; p. 4. Available online: https:/ / www.bmwi.de/Redaktion/DE/Publikationen/Studien/digitalisierung-der-energiewende-thema-2.pdf?_blob= publicationFile\&v=6 (accessed on 6 August 2020).

58. Bundesnetzagentur. Stromnetz Zukunftssicher Gestalten. 2020. Available online: https:/ / www.netzausbau.de/bedarfsermittlung/ 2022/archiv / de.html;jsessionid=D6CE223B06F56187A2AAEE74A3894EAE (accessed on 6 August 2020).

59. EEG. Gesetz für den Ausbau erneuerbarer Energien (ErneuerbareEnergien-Gesetz-EEG 2017). §28. 2020. Available online: http:/ / www.gesetze-im-internet.de/eeg_2014/EEG_2017.pdf (accessed on 5 August 2020).

60. Schreiner, L.; Madlener, R. Investing in power grid infrastructure as a flexibility option: A DSGE assessment for Germany. SSRN 2019. [CrossRef]

61. Lenz, A.K. Eine Institutionenökonomische Analyse der Regulierung der Betreiber der Onshore-Stromübertragungsnetze und Offshore-Windpark-Anbindungen in Deutschland. Ph.D. Thesis, Technischen Universität Berlin, Berlin, Germany, 2019; pp. 232-240.

62. Athamna, I. Zuverlässigkeitsberechnung von Offshore-Windparks. Ph.D. Thesis, Universität Wuppertal, Fakultät für Elektrotechnik, Informationstechnik und Medientechnik, Wuppertal, Germany, 2018; p. 110.

63. EEG. Gesetz für den Ausbau erneuerbarer Energien (ErneuerbareEnergien-Gesetz-EEG 2017). §16. 2020. Available online: http:/ / www.gesetze-im-internet.de/eeg_2014/EEG_2017.pdf (accessed on 5 August 2020).

64. EEG. Gesetz für den Ausbau erneuerbarer Energien (ErneuerbareEnergien-Gesetz-EEG 2017). §72. 2020. Available online: http:/ / www.gesetze-im-internet.de/eeg_2014/EEG_2017.pdf (accessed on 5 August 2020).

65. Netzentwicklungsplan Strom. Stromnetze. 2020. Available online: https://www.netzentwicklungsplan.de/de/wissen/ stromnetze (accessed on 6 August 2020). 
66. European Commission. Quarterly Report on European Electriciy Markets. 2020. Available online: https:/ / ec.europa.eu/energy / sites/ener/files/qr_electricity_q1_2020.pdf (accessed on 6 August 2020).

67. EEG. Gesetz für den Ausbau erneuerbarer Energien (ErneuerbareEnergien-Gesetz-EEG 2017). §56 (1). 2020. Available online: http:/ / www.gesetze-im-internet.de/eeg_2014/EEG_2017.pdf (accessed on 5 August 2020).

68. Bundesministerium für Wirtschaft und Energie. Förderung der erneuerbaren Energien: Wettbewerbliche Vergütung seit dem 1 Januar 2017. 2020. Available online: https://www.bmwi.de/Redaktion/DE/Artikel/Energie/foerderung-der-erneuerbarenenergien.html (accessed on 6 August 2020).

69. Breitkopf, A. Industriestrompreise (inkl. Stromsteuer) in den Jahren 1998 bis 2021. 2020. Available online: https:/ / de.statista. com/statistik/daten/studie/252029/umfrage/industriestrompreise-inkl-stromsteuer-in-deutschland/ (accessed on 6 August 2020).

70. Strom-Report. Electricity prices in Europe-who pays the most? 2020. Available online: https://strom-report.de/electricityprices-europe/\#: \{\{:text=The \%20average \%20values \%20vary \%20significantly,cents $\% 20 \% 7 \mathrm{C} \% 20 \mathrm{kWh} \% 2010 \% 20 \mathrm{years} \% 20 \mathrm{ago}$. (accessed on 6 August 2020).

71. Trinomics. Study on Energy Prices, Costs and Subsidies and their Impact on Industry and Households Rotterdam; Trinomics: Roterdam, The Netherlands, 2018; p. 73. Available online: https:/ / www.enerdata.net/about-us/company-news/energy-prices-and-costsin-europe.pdf (accessed on 6 August 2020).

72. Eurostat. Strompreisstatistik, Strompreise für Private Haushalte. 2019. Available online: https: / /ec.europa.eu/eurostat/statisticsexplained/index.php?title=Electricity_price_statistics /de\#Strompreise_f.C3.BCr_Nichthaushaltskunden (accessed on 6 August 2020).

73. Bardt, H.; Schaefer, T. Ensuring industrial competitiveness with a unified European approach to sustainable energy. In The European Dimension of Germany's Energy Transition; Springer: Berlin/Heidelberg, Germany, 2019; pp. $265-281$.

74. Agora Energiewende. Zehn fragen und antworten zu EEG 2017, strommarkt-und digitalisierungsgesetz. In Energiewende: Was bedeuten die neuen Gesetze; Agora Energiewende: Berlin, Germany, 2020; pp. 18-19. Available online: https://www.agoraenergiewende.de/fileadmin2/Projekte/2016/EEG-FAQ/Agora_Hintergrund_FAQ-EEG_WEB.pdf (accessed on 5 August 2020).

75. Agora Energiewende. Toolbox für die Stromnetze; Agora Energiewende: Berlin, Germany, 2018; Available online: https:/ www agora-energiewende.de/fileadmin2/Projekte/2017/Innovative_Netze_Toolbox/Agora_Netze_Toolbox_WEB.pdf (accessed on 7 August 2020).

76. Golden, W.; Powell, P. Towards a definition of flexibility: In search of the Holy Grail? Omega 2000, 28, 373-384. [CrossRef]

77. Føllesdal, A. Survey article: Subsidiarity. J. Political Philos. 1998, 6, 190-218. [CrossRef]

78. BDI (Bundesverband der Deutschen Industrie e.V.). Handlungsempfehlungen für ein IKT-gestütztes Stromnetz der Zukunft. In Impulse für Eine Smarte Energiewende; BDI: Berlin, Germany, 2013; p. 9. Available online: https://bdi.eu/media/presse/ publikationen/energie-und-rohstoffe/BDI_Impulse_fuer_eine_smarte_Energiewende.pdf (accessed on 6 August 2020).

79. Günther, L. Präsentation auf der tagung wie wird die digitale stromversorgung resilienter? In Zellulare Energienetze als Ansatz für eine Resiliente Energieversorgung; Bergische Universität Wuppertal: Wuppertal, Germany, 2017; Available online: https://www.strom-resilienz.de/data/stromresilienz/user_upload/Dateien/G\%C3\%Bcnther_Zellulare_Energienetze_als_ Ansatz_fuer_eine_resiliente_Energieversorgung.pdf (accessed on 6 August 2020).

80. VDE/ETG-Studie. Der Zellulare Ansatz Grund-lage Einer Erfolgreichen, Regionenübergreifenden Energiewende; VDE-Studie, Energietechnische Gesellschaft im Verband der Elektrotechnik, Elektronik, Informationstechnik: Frankfurt, Germany, 2015; Available online: VDE_ST_ETG_ZellulareAnsatz_web.pdf(bund-naturschutz.de) (accessed on 21 April 2021).

81. Günther, L. Präsentation auf der tagung wie wird die digitale stromversorgung resilienter? In Zellulare Energienetze als Ansatz für eine Resiliente Energieversorgung; Bergische Universität Wuppertal: Wuppertal, Germany, 2017; p. 8. Available online: https:/ /www.strom-resilienz.de/data/stromresilienz/user_upload/Dateien/G\%C3\%Bcnther_Zellulare_Energienetze_ als_Ansatz_fuer_eine_resiliente_Energieversorgung.pdf (accessed on 6 August 2020).

82. VDE/ETG-Studie. Der Zellulare Ansatz Grund-lage Einer Erfolgreichen, Regionenübergreifenden Energiewende; VDE-Studie, Energietechnische Gesellschaft im Verband der Elektrotechnik, Elektronik, Informationstechnik: Frankfurt, Germany, 2015; p. 8. Available online: VDE_ST_ETG_ZellulareAnsatz_web.pdf(bund-naturschutz.de) (accessed on 21 April 2021).

83. VDE/ETG-Studie. Der Zellulare Ansatz Grund-lage Einer Erfolgreichen, Regionenübergreifenden Energiewende; VDE-Studie, Energietechnische Gesellschaft im Verband der Elektrotechnik, Elektronik, Informationstechnik: Frankfurt, Germany, $2015 ;$ p. 12. Available online: VDE_ST_ETG_ZellulareAnsatz_web.pdf(bund-naturschutz.de) (accessed on 21 April 2021).

84. Günther, L. Präsentation auf der tagung wie wird die digitale stromversorgung resilienter? In Zellulare Energienetze als Ansatz für eine Resiliente Energieversorgung; Bergische Universität Wuppertal: Wuppertal, Germany, 2017; p. 4. Available online: https:/ / www.strom-resilienz.de/data/stromresilienz/user_upload/Dateien/G\%C3\%Bcnther_Zellulare_Energienetze_ als_Ansatz_fuer_eine_resiliente_Energieversorgung.pdf (accessed on 6 August 2020).

85. Bundesnetzagentur. Flexibilität in Stromversorgungssystemen; Bundesnetzagentur: Bonn, Germany, 2017.

86. Webster, J.; Watson, R.T. Analyzing the past to prepare for the future: Writing a literature review. MIS Q. 2002, $26,13-23$.

87. Ambrosius, M.; Grimm, V.; Kleinert, T.; Liers, F.; Schmidt, M.; Zöttl, G. Endogenous price zones and investment incentives in electricity markets: An application of multilevel optimization with graph partitioning. Energy Econ. 2020, 92, 104879. [CrossRef]

88. Andoni, M.; Robu, V.; Flynn, D.; Abram, S.; Geach, D.; Jenkins, D.; Peacock, A. Blockchain technology in the energy sector: A systematic review of challenges and opportunities. Renew. Sustain. Energy Rev. 2019, 100, 143-174. [CrossRef] 
89. Agung, A.A.G.; Handayani, R. Blockchain for smart grid. J. King Saud Univ. Comput. Inf. Sci. 2020. [CrossRef]

90. AlSkaif, T.; van Leeuwen, G. Decentralized optimal power flow in distribution networks using blockchain. In Proceedings of the 2nd International Conference on Smart Energy Systems and Technologies, Porto, Portugal, 9-11 September 2019; pp. 1-6.

91. AlSkaif, T.; Holthuizen, B.; Schram, W.; Lampropoulos, I.; van Sark, W. A blockchain-based configuration for balancing the electricity grid with distributed assets. World Electr. Veh. J. 2020, 11, 62. [CrossRef]

92. Devine, M.T.; Cuffe, P. Blockchain electricity trading under demurrage. IEEE Trans. Smart Grid 2019, 10, 2323-2325. [CrossRef]

93. D'Oriano, L.; Mastandrea, G.; Rana, G.; Raveduto, G.; Croce, V.; Verber, M.; Bertoncini, M. Decentralized blockchain flexibility system for smart grids: Requirements engineering and use cases. In Proceedings of the International IEEE Conference and Workshop in Óbuda on Electrical and Power Engineering (CANDO-EPE), Budapest, Hungary, 20-21 November 2018; pp. 39-44.

94. Fang, X.; Misra, S.; Xue, G.; Yang, D. Smart grid-The new and improved power grid: A survey. IEEE Commun. Surv. Tutor. 2011, 14, 944-980. [CrossRef]

95. Gao, J.; Asamoah, K.O.; Sifah, E.B.; Smahi, A.; Xia, Q.; Xia, H.; Dong, G. GridMonitoring: Secured sovereign blockchain based monitoring on smart grid. IEEE Access 2018, 6, 9917-9925. [CrossRef]

96. Gong, G.; Zhang, Z.; Zhang, X.; Mahato, N.K.; Liu, L.; Su, C.; Yang, H. Electric power system operation mechanism with energy routers based on qos index under blockchain architecture. Energies 2020, 13, 418. [CrossRef]

97. Guan, Z.; Si, G.; Zhang, X.; Wu, L.; Guizani, N.; Du, X.; Ma, Y. Privacy-preserving and efficient aggregation based on blockchain for power grid communications in smart communities. IEEE Commun. Mag. 2018, 56, 82-88. [CrossRef]

98. Kotthaus, K.; Hermanns, J.; Paulat, F.; Pack, S.; Meese, J.; Neusel-Lange, N.; Braje, T. Concrete design of local flexibility markets using the traffic light approach. In Proceedings of the CIRED Workshop, Ljubljana, Slovenia, 7-8 June 2018.

99. Kouveliotis-Lysikatos, I.; Kokos, I.; Lamprinos, I.; Hatziargyriou, N. Blockchain-powered applications for smart transactive grids. In Proceedings of the IEEE PES Innovative Smart Grid Technologies Europe (ISGT-Europe), Bucharest, Romania, 29 September-2 October 2019; pp. 1-5.

100. La Fauci, R.; Yang, X.X.; Ma, W.; Luan, W. Implementing the standardization framework to support the development of non-conventional distribution networks/microgrids development of non-conventional distribution networks/microgrids. In Proceedings of the Cired Workshop, Ljubljana, Slovenia, 7-8 June 2018.

101. Lazaroiu, G.C.; Roscia, M. Blockchain and smart metering towards sustainable prosumers. In Proceedings of the International Symposium on Power Electronics, Electrical Drives, Automation and Motion (SPEEDAM), Amalfi, Italy, 20-22 June 2018; pp. 550-555.

102. Li, Y.; Chen, G. Great revolution: The business perspective of energy internet in China. In Proceedings of the CIRED Workshop, Ljubljana, Slovenia, 7-8 June 2018; p. 8.

103. Marinopoulos, A.; Vasiljevska, J.; Mengolini, A. Local energy communities: An insight from European smart grid projects. In Proceedings of the CIRED Workshop, Ljubljana, Slovenia, 7-8 June 2018.

104. Pop, C.; Cioara, T.; Antal, M.; Anghel, I.; Salomie, I.; Bertoncini, M. Blockchain based decentralized management of demand response programs in smart energy grids. Sensors 2018, 18, 162. [CrossRef]

105. Samuel, O.; Javaid, N.; Awais, M.; Ahmed, Z.; Imran, M.; Guizani, M. A blockchain model for fair data sharing in deregulated smart grids. In Proceedings of the IEEE Global Communications Conference (GLOBECOM), Waikoloa, HI, USA, 9-13 December 2019; pp. 1-7.

106. Schmidt, R.; Schnittmann, E.; Meese, J.; Müller, T.; Zdrallek, M.; Armoneit, T. Identification and evaluation of marketing opportunities for flexibility in local energy communities. In Proceedings of the Cired Workshop, Ljubljana, Slovenia, 7-8 June 2018.

107. Stevanoni, C.; Vallée, F.; de Grève, Z.; Deblecker, O. Optimized decentralized and centralized load management techniques in industrial microgrids. In Proceedings of the Cired Workshop, Ljubljana, Slovenia, 7-8 June 2018.

108. Verma, P.; O’Regan, B.; Hayes, B.; Thakur, S.; Breslin, J.G. EnerPort: Irish blockchain project for peer-to-peer energy trading. Energy Inform. 2018, 1, 1-9. [CrossRef]

109. Wang, S.; Taha, A.F.; Wang, J.; Kvaternik, K.; Hahn, A. Energy crowdsourcing and peer-to-peer energy trading in blockchainenabled smart grids. IEEE Trans. Syst. Man Cybern. Syst. 2019, 49, 1612-1623. [CrossRef]

110. Wörner, A.; Meeuw, A.; Ableitner, L.; Wortmann, F.; Schopfer, S.; Tiefenbeck, V. Trading solar energy within the neighborhood: Field implementation of a blockchain-based electricity market. Energy Inform. 2019, 2, 1-12. [CrossRef]

111. Xu, Y.; Ahokangas, P.; Yrjölä, S.; Koivumäki, T. The fifth archetype of electricity market: The blockchain marketplace. Wirel. Netw. 2019, 9, 1-17. [CrossRef]

112. Zhang, Y.; Gu, C.; Li, F. Distributed iterative local energy bidding in agent-based microgrids. In Proceedings of the Cired Workshop, Ljubljana, Slovenia, 7-8 June 2018.

113. Zhao, Y.; Peng, K.; Xu, B.; Liu, Y.; Xiong, W.; Han, Y. Applied engineering programs of energy blockchain in US. Energy Procedia 2019, 158, 2787-2793. [CrossRef]

114. Christidis, K.; Devetsikiotis, M. Blockchains and smart contracts for the internet of things. IEEE Access 2016, 4, $2292-2303$. [CrossRef]

115. Notheisen, B.; Cholewa, J.B.; Shanmugam, A.P. Trading real-world assets on blockchain. Bus. Inf. Syst. Eng. 2017, 59, 425-440. [CrossRef]

116. Chiu, J.; Koeppl, T.V. Blockchain-based settlement for asset trading. Rev. Financ. Stud. 2019, 32, 1716-1753. [CrossRef] 
117. Pan, Y.; Zhang, X.; Wang, Y.; Yan, J.; Zhou, S.; Li, G.; Bao, J. Application of blockchain in carbon trading. Energy Procedia 2019, 158, 4286-4291. [CrossRef]

118. Chen, S.Y.; Song, S.F.; Li, L.X.; Shen, J. Survey on smart grid technology. Power Syst. Technol. 2009, 33, 1-7.

119. Ekanayake, J.B.; Jenkins, N.; Liyanage, K.; Wu, J.; Yokoyama, A. Smart Grid: Technology and Applications; John Wiley \& Sons: Hoboken, NJ, USA, 2012.

120. Xue-Song, Z.; Li-Qiang, C.; You-Jie, M. Research on smart grid technology. In Proceedings of the International Conference on Computer Application and System Modeling (ICCASM 2010), Taiyuan, China, 22-24 October 2010; pp. V3-V599.

121. Gungor, V.C.; Sahin, D.; Kocak, T.; Ergut, S.; Buccella, C.; Cecati, C.; Hancke, G.P. Smart grid technologies: Communication technologies and standards. IEEE Trans. Ind. Inform. 2011, 7, 529-539. [CrossRef]

122. Li, Y.; Chen, G. Great revolution: The business perspective of energy internet in China. In Proceedings of the Cired Workshop, Ljubljana, Slovenia, 7-8 June 2018; p. 13.

123. Gawron-Deutsch, T.; Apel, R.; Diwold, K.; Einfalt, A.; Mosshammer, R.; Lugmaier, A. Marktbasierter ansatz für die koordination von markt und netz. In Von Smart Grids zu Smart Markets; Energietechnische Gesellschaft im VDE (ETG): Frankfurt, Germany, 2015; pp. 25-26.

124. Samuel, O.; Javaid, N.; Awais, M.; Ahmed, Z.; Imran, M.; Guizani, M. A blockchain model for fair data sharing in deregulated smart grids. In Proceedings of the IEEE Global Communications Conference (GLOBECOM), Waikoloa, HI, USA, 9-13 December 2019; pp. 7-11.

125. Lund, H.; Østergaard, P.A.; Connolly, D.; Ridjan, I.; Mathiesen, B.V.; Hvelplund, F.; Sorknæs, P. Energy storage and smart energy systems. Int. J. Sustain. Energy Plan. Manag. 2016, 11, 3-14.

126. Krajačić, G.; Duić, N.; Zmijarević, Z.; Mathiesen, B.V.; Vučinić, A.A.; da Graça Carvalho, M. Planning for a 100\% independent energy system based on smart energy storage for integration of renewables and $\mathrm{CO}_{2}$ emissions reduction. Appl. Therm. Eng. 2011, 31, 2073-2083. [CrossRef]

127. Speh, R.M. Der Zellulare Ansatz-Grundlage einer Erfolgreichen, Regionen Übergreifenden Energiewende; Energietechnische Gesellschaft im VDE (ETG): Frankfurt, Germany, 2016; Available online: http:/ / www.ecotrinova.de/downloads/2016/160702-Prof_SpehZellularerAnsatzVDE-GET_Vortragprint.pdf (accessed on 6 August 2020).

128. Schreiber, M.; Wainstein, M.E.; Hochloff, P.; Dargaville, R. Flexible electricity tariffs: Power and energy price signals designed for a smarter grid. Energy 2015, 93, 2568-2581. [CrossRef]

129. Vlot, M.C.; Knigge, J.D.; Slootweg, J.G. Economical regulation power through load shifting with smart energy appliances. IEEE Trans. Smart Grid 2013, 4, 1705-1712. [CrossRef]

130. Mengelkamp, E.; Gärttner, J.; Rock, K.; Kessler, S.; Orsini, L.; Weinhardt, C. Designing microgrid energy markets: A case study: The Brooklyn microgrid. Appl. Energy 2018, 210, 870-880. [CrossRef]

131. Bundesnetzagentur. Eckpunktepapier—Smart Grid und Smart Market; Bundesnetzagentur: Bonn, Germany, 2011; Available online: https:/ / www.bundesnetzagentur.de/EN/Areas/Energy/Companies/GridDevelopment/SmartGridMarket/SmartGrid html (accessed on 21 April 2021).

132. Bundesnetzagentur. Flexibilität im Stromversorgungssystem. Bestandsaufnahme, Hemmnisse und Ansätze zur Verbesserten Erschließung von Flexibilität; Bundesnetzagentur: Bonn, Germany, 2017.

133. Chen, C.; Duan, S.; Cai, T.; Liu, B.; Hu, G. Smart energy management system for optimal microgrid economic operation. IET Renew. Power Gener. 2011, 5, 258-267. [CrossRef]

134. Zdrallek, M. Regionale Flexibilitätsmärkte zur Entlastung des Verteilnetzes. 2018. Available online: https: / / edna-bundesverband. de/wp-content/uploads/2019-11-21-ZDRALLEK-RegioFlex_final.pdf (accessed on 5 August 2020).

135. Lund, H.; Andersen, A.N.; Østergaard, P.A.; Mathiesen, B.V.; Connolly, D. From electricity smart grids to smart energy systems-A market operation based approach and understanding. Energy 2012, 42, 96-102. [CrossRef]

136. Zander, W.; Rosen, U.; Nolde, A. Regulierung, flexibilisierung und sektorkopplung. In Erstellt im Auftrag des Bundesministeriums für Wirtschaft und Energie; Federal Ministry of Economics and Technology: Berlin, Germany, 2018; p. 20. Available online: https:/ / www.bmwi.de/Redaktion/DE/Publikationen/Studien/digitalisierung-der-energiewende-thema-2.pdf?_blob= publicationFile\&v=6 (accessed on 6 August 2020).

137. Pöppe, M. Smart market—Konzept und nutzen. In Energy 2.0 Kompendium; Publish-industry Verlag GmbH: Munich, Germany, 2012; pp. 84-87.

138. Colak, I.; Sagiroglu, S.; Fulli, G.; Yesilbudak, M.; Covrig, C.F. A survey on the critical issues in smart grid technologies. Renew. Sustain. Energy Rev. 2016, 54, 396-405. [CrossRef]

139. Gesetz über den Messstellenbetrieb und die Datenkommunikation in Intelligenten Energienetzen (MessstellenbetriebsgesetzMsbG). Messstellenbetriebsgesetz vom 29. August 2016 (BGBl. I S. 2034), das Zuletzt Durch Artikel 90 des Gesetzes vom 20. November 2019 (BGBl. I S. 1626) Geändert Worden Ist. 2016. Available online: http://www.gesetze-im-internet.de/messbg/ MsbG.pdf (accessed on 8 November 2020).

140. Stahl, A. Startschuss Für Den Smart-Meter-Rollout Ist Gefallen, Energie Messenger.ch. 2020. Available online: https://www. energate-messenger.de/news/199942/startschuss-fuer-den-smart-meter-rollout-ist-gefallen (accessed on 8 November 2020).

141. Lee, L. New kids on the blockchain: How bitcoin's technology could reinvent the stock market. Hastings Bus. Law J. 2015, $12,81$. [CrossRef] 
142. Sikorski, J.J.; Haughton, J.; Kraft, M. Blockchain technology in the chemical industry: Machine-to-machine electricity market. Appl. Energy 2017, 195, 234-246. [CrossRef]

143. Mautz, R.; Byzio, A.; Rosenbaum, W. Auf dem Weg zur Energiewende. Die Entwicklung der Stromproduktion aus erneuerbaren Energien in Deutschland; Eine Studie aus dem Soziologischen Forschungsinstitut Göttingen (SOFI); Universitätsverlag Göttingen: Göttingen, Germany, 2008.

144. Gruber, S. Implikationen von Kapazitätsmärkten auf das Akteursverhalten: Eine spieltheoretische Analyse des Investitionsverhaltens deutscher Energieerzeuger; Springer Gabler: Wiesbaden, Germany, 2015.

145. Fraunhofer ISE. Aktuelle Fakten zur Photovoltaik in Deutschland; Fraunhofer ISE: Freiburg, Germany, 2020; pp. 9-12. Available online: https:/ / www.ise.fraunhofer.de/content/dam/ise/de/documents/publications/studies/aktuelle-fakten-zur-photovoltaikin-deutschland.pdf (accessed on 7 August 2020).

146. Joos, F. Energiewende-Quo vadis? Beiträge zur Energieversorgung; Springer Gabler: Wiesbaden, Germany, 2016.

147. Zimmermann, F.M.; Pizzera, J. Globalisierung und ökonomische nachhaltigkeit—Schein oder sein? In Nachhaltigkeit Wofür; Springer: Berlin/Heidelberg, Germany, 2016; pp. 85-112.

148. Felber, C. Die Gemeinwohl-Ökonomie: Eine Demokratische Alternative wächst; Deuticke: Vienna, Austria, 2012.

149. Brunner, F.; Drage, T. Nachhaltigkeit in der stadt-Von herausforderungen, partizipation und integrativen konzepten. In Nachhaltigkeit Wofür; Springer: Berlin/Heidelberg, Germany, 2016; pp. 113-146.

150. Sensfuß, F. Analysen zum Merit-Order Effekt Erneuerbarer Energien; Update für das Jahr; Fraunhofer-Institut für System- und Innovationsforschung (ISI): Karlsruhe, Germany, 2010.

151. Clò, S.; Cataldi, A.; Zoppoli, P. The merit-order effect in the Italian power market: The impact of solar and wind generation on national wholesale electricity prices. Energy Policy 2015, 77, 79-88. [CrossRef]

152. McConnell, D.; Hearps, P.; Eales, D.; Sandiford, M.; Dunn, R.; Wright, M.; Bateman, L. Retrospective modeling of the merit-order effect on wholesale electricity prices from distributed photovoltaic generation in the Australian national electricity market. Energy Policy 2013, 58, 17-27. [CrossRef]

153. Cludius, J.; Hermann, H.; Matthes, F.C.; Graichen, V. The merit order effect of wind and photovoltaic electricity generation in Germany 2008-2016: Estimation and distributional implications. Energy Econ. 2014, 44, 302-313. [CrossRef]

154. Stellungnahme des Umweltbundesamtes (UBA). Konsultation des BMWi-Grünbuchs „Ein Strommarkt für die Energiewende“; The Umweltbundesamt: Dessau-Roßlau, Germany, 2015.

155. Pham, T.; Lemoine, K. Impacts of Subsidized Renewable Electricity Generation on Spot Market Prices in Germany: Evidence from a Garch Model with Panel Data; Paris Dauphine University: Paris, France, 2020.

156. Eid, C.; Codani, P.; Chen, Y.; Perez, Y.; Hakvoort, R. Aggregation of demand side flexibility in a smart grid: A review for European market design. In Proceedings of the 12th International Conference on the European Energy Market (EEM), Lisbon, Portugal, 19-22 May 2015; pp. 1-5. 